NBER WORKING PAPER SERIES

\title{
CAPITAL ALLOCATION AND DELEGATION OF DECISION-MAKING AUTHORITY WITHIN FIRMS
}

John R. Graham

Campbell R. Harvey

Manju Puri

Working Paper 17370

http://www.nber.org/papers/w17370

\author{
NATIONAL BUREAU OF ECONOMIC RESEARCH \\ 1050 Massachusetts Avenue \\ Cambridge, MA 02138 \\ August 2011
}

We thank Andy Clifton, Kees Koedijk, Peter Roosenboom, Susan Simko and Cheri Varnadoe for their help in implementing the survey, and Chief Executive magazine, CFO magazine, CFO Asia, and CFO Europe for allowing us to survey their subscribers. We thank Patrick Bolton, Bob Gibbons, Oliver Hart, Jennifer Huang, Mike Minnis, Oguz Ozbas, Zekiye Selvili, Jeremy Stein, Julie Wulf, Marc Zenner, and seminar participants at Duke University, the Harvard/MIT Organizational Economics seminar, North Carolina State University, Penn State, SMU, and University of Texas-Austin for providing helpful comments. Special thanks to Martine Cools, Abe de Jong, Frank Ecker, Nadja Guenster, and Bruno Laranjeira for translating the survey. We appreciate the excellent research assistance of Ben Ee and Nikhil Sharma. The views expressed herein are those of the authors and do not necessarily reflect the views of the National Bureau of Economic Research.

NBER working papers are circulated for discussion and comment purposes. They have not been peerreviewed or been subject to the review by the NBER Board of Directors that accompanies official NBER publications.

(C) 2011 by John R. Graham, Campbell R. Harvey, and Manju Puri. All rights reserved. Short sections of text, not to exceed two paragraphs, may be quoted without explicit permission provided that full credit, including $\odot$ notice, is given to the source. 
Capital Allocation and Delegation of Decision-Making Authority within Firms

John R. Graham, Campbell R. Harvey, and Manju Puri

NBER Working Paper No. 17370

August 2011

JEL No. G30,G32,G34,L20,L22

\begin{abstract}
$\underline{\text { ABSTRACT }}$
We survey more than 1,000 CEOs and CFOs to understand how capital is allocated, and decision-making authority is delegated, within firms. We find that CEOs are least likely to share or delegate decision-making authority in mergers and acquisitions, relative to delegation of capital structure, payout, investment, and capital allocation decisions. We also find that CEOs are more likely to delegate decision authority when the firm is large or complex. Delegation is less likely when the CEO is particularly knowledgeable about a project, when the CEO has an MBA degree or long tenure, and when the CEO's pay is tilted towards incentive compensation. We study capital allocation in detail and learn that most companies allocate funds across divisions using the net present value rule, the reputation of the divisional manager, the timing of a projects cash flows, and senior management's "gut feel." Corporate politics and corporate socialism are more important allocation criteria in foreign countries than in the U.S.
\end{abstract}

John R. Graham

Duke University

Fuqua School of Business

100 Fuqua Drive

Durham, NC 27708-0120

and NBER

john.graham@duke.edu

Campbell R. Harvey

Duke University

Fuqua School of Business

प्रा) XIXD' UYH

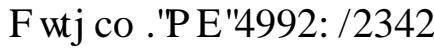

and NBER

cam.harvey@duke.edu
Manju Puri

' XNH8 QYHHUW

Fuqua School of Business

प००() XIXD' UYH

Durham, NC 27708-0120

and NBER

mpuri@duke.edu 


\section{Introduction}

In recent years, the companies in Standard and Poor's Compustat database annually invested more than \$1 trillion, paid out more than \$1 trillion via dividends and share repurchases, and completed mergers and acquisitions worth nearly $\$ 500$ billion. Hundreds of research papers have studied the causes and consequences of these corporate policies. However, much less is known about how corporate decisions are made and by whom, which is the topic of this paper. We also explore capital allocation in detail, investigating which factors are most important in internally distributing capital across corporate divisions.

Theoretical research examines how decision-making authority is delegated within groups. While the theoretical implications are far-ranging, there has been a scarcity of empirical evidence about the delegation of authority within corporations (as noted by Prendergast (2002) and others). This paper provides some of the first empirical evidence that focuses on the delegation of decision-making authority with respect to major corporate policies. ${ }^{1}$ In particular, we study whether the chief executive makes decisions on her own or delegates to lower-level executives and others on the management team.

We survey CEOs and CFOs to determine who within the firm makes five different corporate decisions: capital allocation, capital structure, investment, mergers and acquisitions, and payout. Most of our analysis focuses on the 950 CEO and 525 CFO survey respondents who work in U.S.-based companies, though we also examine smaller samples of Asian and European executives. Knowing the job title of the corporate decision-maker is important, given recent

\footnotetext{
${ }^{1}$ Several papers study employee discretion in the context of incentive pay. Baiman et al. (1995) examine a binary delegation measure of business unit control of core functions among firms included in a compensation survey. Nagar (2002) studies the discretion of 100 bank branch managers in choosing branch hours, hiring tellers, awarding promotions, and choosing which new investment products to sell. Aggarwal and Samwick (2003) examine how performance-pay sensitivity varies by Execucomp job title. Moers (2006) surveys 105 managers at six firms and links the contractibility (i.e., sensitivity, precision, and verifiability) of bonus plans to delegation of personnel, budgeting, and pricing decisions. Ortega (2009) studies individual interviews that are the basis of the European Working Conditions Surveys and links incentive pay to discretion in lower level employee work methods and scheduling. Other papers reviewed below.
} 
evidence that executive-specific effects appear to drive some corporate policies. ${ }^{2}$ Our paper contrasts with and complements this stream of research. These papers study the outcome and drivers of various corporate decisions, while our paper documents how these decisions are made and by whom. These topics are obviously related because it would not be possible for an executive to influence the outcome of a decision if he were not involved in the decision-making process. As Alonso and Matouschek (2007) put it, "an understanding of what determines the internal allocation of decisions rights is ... a prerequisite for understanding, and potentially being able to predict, the decisions that firms make, such as how much to invest..." (p. 1070). Therefore, it is important to understand who is involved in corporate decision-making, which is a dimension that our research adds to the literature.

A growing theoretical literature provides the framework that we use to empirically study the delegation of decision-making authority. Harris and Raviv (2005) model how CEOs trade off the benefit of incorporating the information of divisional managers with the empire-building desires of those same managers. Among other things, they conclude that delegation is less likely for projects that involve new products or locations, while delegation increases with the span of CEO control. Van den Steen $(2004,2005)$ argues that homogeneous organizations dominated by the CEO's vision suffer fewer agency problems, which in turn leads to more delegated outcomes. Aghion and Tirole (1997) model the trade-off between a CEO's company benefiting from divisional manager initiative versus the CEO giving up control. They find that delegation is most prevalent when the CEO would be overloaded if she tried to make a decision in isolation (like in conglomerates), when lower-level employees are paid with incentive compensation, and for less important decisions such as low cash flow projects. Like Harris and Raviv, they conclude that

\footnotetext{
${ }^{2}$ See, among others, Bertrand and Schoar (2003), Malmandier and Tate (2005; 2007), Ben-David, Graham, and Harvey (2008), Frank and Goyal (2007), and Chava and Purnanandam (2010).
} 
decisions are less likely to be delegated when there are long-term consequences and when there are more external effects.

Our empirical evidence is consistent with several of these theoretical predictions. We find that CEOs are more likely to delegate decision-making authority to lower level employees when their workload is high, and less when the CEO's knowledge is particularly valuable. We also document that CEOs dominate merger and acquisition decisions (more so than CEO dominance of other policies), again consistent with theoretical implications. We document that CEOs delegate less when their pay is incentive-based, when they have MBA degrees, and when they have a background in finance or accounting. In terms of allocating capital across a given firm's divisions, we find that CEOs rely on a NPV ranking of the various projects, which is consistent with textbook recommendations. We also find evidence that other factors importantly affect capital allocation, including the divisional manager's reputation, the timing of when cash flows are produced by a project (which may matter due to financial constraints), and senior management's "gut feel." Interestingly, in the eyes of CFOs, internal corporate politics are believed to affect capital allocation, more so than in the eyes of CEOs. Finally, corporate socialism (that is, even distribution of capital across divisions) and corporate politics are more important overseas than they are in the United States.

Our analysis is based on survey data. This approach allows us to address issues that traditional empirical work based on archival data sources can not. For example, with standard data it is difficult to ascertain who makes a decision within a firm and when that decision is shared versus made in isolation. Typically it is also difficult to determine which criteria are used to make decisions. Using a survey permits us to investigate these issues in detail. By asking 
questions about these and related topics, we are able to obtain an inside look into the corporate decision-making process.

While the survey approach allows one to ask unique questions, it is not without potential issues. Surveys measure beliefs, not necessarily actions. Perhaps some of the survey questions are misunderstood or otherwise produce noisy measures of the desired variables of interest. Moreover, at least for some questions, executives plausibly may parrot explanations that they think researchers want to hear, rather than state their true beliefs. In addition, field studies need to consider that market participants do not necessarily have to understand the reason they do what they do in order to make (close to) optimal decisions. It is also possible that the respondents are not representative of the underlying population, an issue that we investigate below. Given that we conduct our survey at one point in time, it is not possible to statistically determine causation. Even with these considerations, we believe that our study provides unique information about how decisions are made within firms, as well as how capital is allocated. We hope that researchers will use our results to develop new theories or potentially modify existing views.

Several recent empirical papers study delegation. Colombo and Delmastro (2004) survey 438 Italian metalworking firms and find that plant-level workforce and capital spending decisions are delegated more often in large firms and when tasks are urgent, and less in multiplant companies (this last result is opposite ours). Acemoglu et al. (2007) find that a company is more likely to design its units as profit centers (their definition of delegation) when it faces greater uncertainty in decision processes, which the authors argue occurs in firms close to the technology frontier or in industries with large variation in technological capabilities across firms. McElheran (2009) examines the delegation of new IT decisions. Bloom et al. (2009) explore how decentralization varies across countries with the degree of trust and rule of law, and how this 
affects economic efficiency. Our work complements these studies and adds several new dimensions. We investigate how personal characteristics of the CEO (job tenure, educational background, work experience, compensation mix, age), as well as several unique firm characteristics (expected growth, merger history, number of business segments) affect delegation. We also investigate corporate policies (mergers, payout, capital structure, capital allocation) not studied previously in a delegation context, and ours is the only paper to statistically test whether delegation is a company-wide phenomenon (i.e., across different policies). Finally, we study how several unique characteristics (gut feel, managerial and divisional reputation, cash flow timing, and corporate politics) affect capital allocation.

The rest of the paper is organized as follows. Section 2 reviews the literature in the context of developing the hypotheses we test. Section 3 describes the survey instrument and delivery mechanism, explains the design of the questions and variables, and presents summary statistics. Section 4 presents evidence about the decision criteria executives use when allocating capital across projects and divisions. Section 5 analyzes who makes which decision within the firm and under what conditions decision-making authority is delegated to lower level management. Section 6 concludes.

\section{Theory and predictions}

For the most part, the delegation implications that we explore can be considered in the context of a CEO and employees, each of whom have private information and personal objectives (e.g., as in Dessein (2002)). The CEO trades off the cost of giving up control to employees (who would like to build their own mini-empires) versus the benefits of engaging lower-level employees and/or learning their private information. Factors that increase the value 
of the CEO's stake or knowledge (e.g., valuable work experience) will decrease delegation. In contrast, factors that increase the cost of the CEO monitoring the company's lower-level employees and corporate activities (e.g., a large number of disparate divisions within a firm), or factors that decrease the agency desires of employees (e.g., lack of incentive compensation), will increase CEO delegation. See Gibbons (2010) for an overview of models in this class. ${ }^{3}$ The rest of this section expands on this reasoning to develop empirical predictions.

Aghion and Tirole (1997) analyze the degree to which a boss retains formal authority but delegates real decision authority to an employee. The boss balances the cost of giving up control with the benefit of promoting initiative by the employee to act on his information. The authors argue that delegation by CEOs is more credible when the chief executive is overloaded (such as when they manage large, multi-segment, fast-growing firms) because the boss has "too little time to acquire the relevant information on each activity" (p. 3). This is consistent with an implication from Hart and Moore (2005) that the larger number of tasks a boss has under her purview, the more likely it is a lower-level employee will use his own ideas (as opposed to the boss's idea) to implement a given task. Jennergren (1981) summarizes the management literature to indicate that it is natural for a company to become more decentralized, and decisions therefore to be more frequently delegated, as the company grows larger.

Prediction 1: The delegation of corporate decision-making authority increases when the CEO is overloaded and as the firm becomes complex.

We posit that CEOs are more likely to be overloaded when their firms are complex (multidivisional) or large (as measured by total assets). Delegation may also increase following

\footnotetext{
${ }^{3}$ For related papers, see also Baker, Gibbons, and Murphy (1999), Mookherjee (2006), Alonso and Matouschek (2007), Rajan and Wulf (2006), Alonso, Dessein, and Matouschek (2008), and Rantakari (2008). Also, Freeland (1996) presents an interesting sociological account of M-Form (i.e., decentralization and the resulting separation of strategic and operational decision-making) organizational structure in GM in the early to mid 1900s.
} 
mergers and acquisitions, which often increase the size and complexity of a firm, as well as the workload of upper management. ${ }^{4}$

Aghion and Tirole (1997) argue that delegation is more likely when the principal has a higher cost (than the agent) of becoming informed. Thus, a CEO will delegate less when she is very knowledgeable or well informed, or in relation to activities she has learned from personal experience. Harris and Raviv (2005) analyze a situation in which both the CEO and lower-level manager have private information. While the CEO would like to learn the employee's information via delegation, this must be traded off against the agency cost of the employee's preference for empire. Among other things, Harris and Raviv show that a CEO will delegate less when her private information is particularly important.

Prediction 2: The delegation of corporate decision-making authority decreases with the CEO's knowledge and the importance of her information.

One way that we proxy for the amount and importance of CEO knowledge is based on tenure. We also measure CEO knowledge by whether the CEO has an MBA degree. Finally, given that we examine financial decisions, and Aghion and Tirole argue that delegation is less likely in activities related to expertise the principal has developed through experience, we also consider whether the CEO has previous work experience in finance or accounting to gauge expertise.

When there is a great deal of uncertainty, the cost of information gathering and monitoring increases for the CEO, and hence delegation may increase so as to avoid these costs. For example, Prendergast (2002) investigates the relation between performance-based pay and risk. He concludes that when it is difficult or costly to monitor workers, or upper management has substantial uncertainty about which tasks are optimal for workers to undertake, decision

\footnotetext{
${ }^{4}$ An alternative prediction is that as complexity increases, the need increases for headquarters to control the decision process in order to coordinate across divisions (and therefore, delegation decreases). In an effort to aid exposition, in the text we present a single directional hypothesis rather than competing predictions. In some places below where our empirical evidence is consistent with an alternative prediction, we discuss the alternative view.
} 
authority should be delegated to workers (and simultaneously, to constrain their discretion these employees should be paid with incentive compensation linked to output). In a capital budgeting context, Taggart (1987) also argues that headquarters has more to gain by delegating when uncertainty is high about which future state will be realized. Research about chief executive vision leads to similar implications. Van den Steen (2005) argues that strong CEO vision is very important in uncertain situations and industries (such as high tech). Strong vision in this context means a "strong belief about the right course of action" (p. 256) and leads to a CEO hiring employees who share her vision. As workforce homogeneity increases in this dimension, Van den Steen (2004) argues that agency costs decline and hence delegation increases.

Prediction 3: The delegation of corporate decision-making authority increases when the environment is uncertain.

Columbo and Delmastro (2004) argue that business uncertainty is higher in high-tech settings. Accordingly, we predict that in high-tech industries, uncertainty is high, as is delegation.

The objectives of the CEO and employees are more likely to be aligned, and therefore empire building agency costs smaller, when employees are paid with incentive compensation. As just mentioned, Prendergast (2002) argues that delegated decision-making and incentive compensation are positively related (because uncertainty leads to both delegation and pay linked to worker output). In their analysis of the trade-off of delegation leading to more divisional manager initiative versus the CEO ceding control, Aghion and Tirole (1997) argue that in industries in which it is hard to provide incentive compensation, CEOs retain more control and delegate less. ${ }^{5}$ Thus, these theories predict that delegation of corporate decision-making authority should be positively correlated with the extent to which divisional managers are paid with

\footnotetext{
${ }^{5}$ In a similar vein, Van den Steen (2010) argues that CEO authority over employees (i.e., the CEO telling employees what to do and employees following this order even when at times it goes against their own preferences) declines as employee incentive compensation increases. Similarly, Rantakari (2008) concludes that centralized authority and incentive alignment are substitutes.
} 
incentive compensation. These predictions are about employee incentives. What about CEO pay? Several models (e.g., Aghion and Tirole; Harris and Raviv; Hart and Holmstrom (2009)) make the point that when the CEO cares more about the outcome of a decision, she will delegate less. ${ }^{6}$ In our setting, when the pay of the CEO is heavily incentive-based she will care a great deal about the outcome of a decision. This would motivate the CEO to retain more decision-making control, and lead to a negative relation between delegation and the proportion of (CEO) pay that is incentive-based.

Prediction 4: The relation between the delegation of corporate decision-making authority and employee incentive pay is positive. The relation between delegation and CEO incentive pay is negative.

We only have compensation data for the survey respondent (e.g., the proportion of CEO pay that comes from variable compensation), and the second sentence of the prediction indicates that there should be a negative relation between CEO variable compensation and delegation. However, it is possible that the degree of CEO incentive pay is positively correlated with the degree to which lower level employees receive incentive pay. Ignoring CEO incentives, this would imply a positive relation between delegation and the proportion of pay that is incentivebased, as described in the first sentence of Prediction 4. Overall, the empirical evidence will indicate which effect dominates, if either.

Taggart (1987) argues that when a firm has growth potential, it is possible that several divisions may simultaneously demand capital in order to exercise their respective growth options. Such behavior could outstrip headquarter's ability to raise capital. In order to control the timing of growth option exercises, headquarters of growth firms should retain control of

\footnotetext{
${ }^{6}$ In Hart and Holmstrom (2009), the boss delegates formal authority over decision rights to divisional managers and has incentive not to renege, which would aggrieve the employees and lead them to exert less effort. In this setting, the boss effectively delegates fewer decisions when she cares a lot about the outcome and delegates more when the decisions matter more to lower employees.
} 
divisional assets and decisions about which investments to pursue. In Marino and Matsusaka (2005), the CEO prefers to delegate in situations where a low quality employee would mimic a high quality worker, such as low-payoff projects whose output does not vary much with quality. They predict less delegation for projects with high upside potential, such as growth projects, because in these cases headquarters wants to retain approval rights. $^{7}$

Prediction 5: The delegation of corporate decision-making authority decreases with the growth opportunities of the firm.

We measure growth opportunities based on expected future sales revenue growth rates.

The predictions thus far relate the extent to which delegation varies conditional on firm or employee characteristics. The next hypothesis describes the type of decisions one might expect to be delegated. In Harris and Raviv (2005), strategic decisions such as expanding into a new industry or product line are likely to be more closely related to the global perspective and information of the CEO (in contrast to the detailed, "plant level" information of lower level employees). These authors hence predict less delegation in "decisions to acquire other firms relative to decisions to undertake internal investments" (p. 368). Assuming that CEOs have a lower cost (than do employees) of becoming informed about external projects, Aghion and Tirole (1997) similarly predict less delegation authority in external (versus internal) projects. Taggart (1987) predicts the same for allocation of capital.

Prediction 6: The delegation of decision authority decreases in decisions that involve new product lines or new industries.

We test this prediction by examining the extent to which CEOs delegate merger and acquisition decisions relative to delegation of other decisions.

\footnotetext{
${ }^{7}$ A counter-prediction can be made that growth firms should experience more delegation, perhaps because of growth-driven firm complexity (e.g., Aghion and Tirole (1997)).
} 
The final hypothesis is phrased in the context of capital allocation to best use the data we have available to examine the prediction. Stein (2003, p. 145) argues that rationing capital based on managerial reputation is consistent with divisional managers having valuable information about investment prospects and headquarters allocating capital in an effort to elicit this private information. In Ozbas' (2005) model of internal capital allocation, divisional managers have unique expertise but they also have agency desires, so they are tempted to exaggerate project payoffs to increase their allocation of resources. In his model, the perceived talent (and remuneration) of managers falls ex post if they do not deliver the expected results. Therefore, high reputation managers (who have more to lose if they do not deliver) are more likely to provide truthful information to headquarters, and in turn headquarters has good reason to allocate capital based on reputation. Dessein (2007) studies when a CEO makes decisions as a dictator (i.e., with no delegation or sharing of decision authority). Dessein's model suggests that it is not worth incurring the cost of communicating with (in order to delegate to) divisional managers for low profit / low success projects. Assuming that past success is correlated with expectations about future success, we posit that delegation and capital allocation are higher when the divisional manager has developed a reputation for delivering on past projects (i.e., has a past record of success).

Prediction 7: Divisional managers are allocated more capital when their past success and reputation are greater.

We test this prediction in the context of capital allocation using two factors: whether capital allocation decisions are based on divisional manager reputation; or alternatively, past divisional success. Jennergren (1981) states that decentralization is often implemented via divisional capital allocation. Therefore, by studying whether internal capital allocation is tied to past success, we draw inference whether delegation is tied to reputation and past success. 


\section{Data gathering, variable definitions and summary statistics}

\subsection{Survey mechanism}

Measuring the process behind corporate decision-making is inherently difficult. One approach relies on financial statement data for public firms, perhaps complementing these data by trying to infer an executive's personal traits or deducing managerial involvement via fixed effects regression coefficients. We adopt a different approach in which we gather information using surveys. As far as we are aware, no other study attempts to address the capital allocation issues we address or directly gauge the delegation of decision-making authority for the five major corporate decisions that we study.

\subsection{Survey data}

We collect three primary types of information via the survey: the criteria that executives use when allocating capital within their firms, how decision-making authority is shared within the firm for five different corporate policies, and demographics about the executives and their firms. ${ }^{8}$ Below we define the key variables that we use in this study.

\subsubsection{Capital allocation questions}

We ask CEOs and CFOs about the decision criteria they use when deciding how to allocate capital across divisions. We ask executives how the following 10 criteria or decision rules affect capital allocation at their companies. The left column shows the short-hand way we refer in the text to a given criterion. The right column shows the choices available to executives

\footnotetext{
${ }^{8}$ Graham et al. (2010) examine several questions from this survey that are not studied in this paper.
} 
as they answer the following question: Which of the following factors are important in your allocation of capital across divisions?

\begin{tabular}{|c|c|}
\hline Balanced Allocation & "Moving towards an even balance of capital allocation across divisions" \\
\hline Manager Reputation & "The reputation of the divisional manager in terms of delivering on previous projects" \\
\hline Internal / External & "Whether the project requires external capital (vs. funding with internal funds)" \\
\hline Gut Feel & "Senior management's 'gut feel' " \\
\hline NPV Rank & "NPV ranking of project" \\
\hline Previous Return & "Return on previous projects earned by the division proposing the project" \\
\hline Manager Confidence & "The confidence of the divisional manager in the project" \\
\hline Cash Flow Timing & "Timing of projects' cash flows" \\
\hline Corporate Politics & "Corporate politics" \\
\hline Market Share & "Protecting market share" \\
\hline
\end{tabular}

The respondents rate each of these 10 criteria on a scale of 1 to 5 , with 1 meaning "not at all important" and 5 meaning "very important." In part of the analysis, we convert into binary form by assigning a given variable a value of 1 if the respondent answered 3 or more out of 5 , indicating that the response is of some importance.

\subsubsection{Delegation of decision-making authority questions}

We ask CEOs and CFOs how much decision-making authority is delegated within their firms with respect to five different corporate policies: capital structure, payout, capital investment, allocating capital across divisions, and mergers and acquisitions. ${ }^{9}$

For each of these policies, we ask executives "Amongst the management team, who has the most input in the following policies?" A response value of 1 indicates that the CEO makes the decision by herself, with no input from others. In other words, 1 indicates that the CEO does not share or delegate decision-making authority at all. A value of 7 indicates that the CEO leaves

\footnotetext{
${ }^{9}$ Capital investment decisions reflect how large the investment "pie" should be, while capital allocation reflects how the pieces of the pie should be divided up internally.
} 
a given decision completely to others within the firm. In other words, 7 indicates the CEO completely delegates a given decision to others. We interpret values from 1 to 7 as indicating an increasing degree of delegation.

\subsubsection{Demographic and career-related variables}

We gather information on the personal characteristics of the executives, their past career/education, and firm demographics. Below we explain how we measure and interpret these variables. All of this information is self-reported by survey respondents.

For executives, we know whether they are the CEO or CFO and in what country their firm is located. They also describe their primary area of work experience. We create a binary variable finance career that indicates whether their career path has primarily been related to finance and accounting, which is potentially relevant because the corporate policies we examine are all financial policies. We inquire whether the executive has an $M B A$ degree. An MBA can signify that the executive is knowledgeable about the financial policies we examine, and therefore less inclined to share decision authority. However, given the "teamwork" that MBA programs emphasize, it is also possible that MBA training will lead to more delegation by the CEO. We also gather information on the respondent's Age. Younger CEOs can potentially be less knowledgeable or otherwise inclined to share decision-making with others in the company.

The executives also tell us how long they have been in their current position. Tenure is a dummy variable which equals 1 if the respondent's tenure at her firm is greater than the median of all respondents. We posit that knowledge about the business increases with tenure, which the theories described in Section 2 imply should lead to less delegation. Finally, we ask the 
executives on average what is "the approximate target percentage of your total compensation that is in the form of stocks, options, or bonus" (Variable Compensation).

We also collect information on a number of company characteristics. We measure firm Size based on sales revenue. We categorize firms as large if they have sales revenues exceeding \$1B. The executives also report the number of distinct operating segments in their firms (segments) and whether their firms are public or private, which we categorize with a binary variable Public. We ask companies how many material mergers or acquisitions they participated in during the previous two years. We create two variables based on the responses. Acquisitions is a binary variable that indicates whether the company took part in any material mergers or acquisitions in the past two years, and multiple acquisitions is a binary variable turned on when the firm participated in two or more.

We ask the CEOs and CFOs to tell us about their firms' growth in sales revenue. Past Growth is a dummy which equals 1 if the respondent firm's average annual growth in sales revenue over the last three years is greater than the $75^{\text {th }}$ percentile of all respondents (and equals 0 otherwise). Expected Growth is a dummy which equals 1 if the respondent firm's projected average annual growth in sales revenue over the next three years is greater than the $75^{\text {th }}$ percentile of all respondents (and equals 0 otherwise).

We also create dummy variables that indicate when a firm operates in the technology (Tech) or manufacturing industries. Finally, we ask companies to report their total debt to total assets ratio (Debt Ratio). 


\subsection{Data and summary statistics}

As detailed in the appendix, we surveyed approximately 10,700 CEOs and obtained 1,180 responses. We also surveyed approximately 9,000 U.S. CFOs (and 10,000 European and Asian CFOs) and received 549 (664) responses. The CEO sample upon which most of our analysis is based has an $11 \%$ response rate that is typical of recent survey response rates; the CFO 6\% response rate is similar to the response on the quarterly CFO survey that relies on the same email lists. ${ }^{10}$ In the appendix we also compare our sample to the Compustat database and find that our sample firms are roughly similar to their counterparts.

Table I contains self-reported summary information about the characteristics of sample firms. In our sample $11.5 \%$ of the firms are public, with mean sales revenue of $\$ 551$ million. While much research studies public firms, one advantage of our sample is that we learn a great deal about private firms. This is important because little private firm analysis is conducted even though government statistics indicate that $87 \%$ of U.S. firms with assets greater than $\$ 10$ million are private. ${ }^{11}$ At the same time, it is important to interpret our results with the public/private breakdown in mind.

The median compnay in our sample has two operating segments and has experienced annual sales growth of $12 \%$ over the past three years, with similar expected future growth. The median debt-to-assets ratio is $20 \%$. The mean (median) number of acquisitions over the past three years is $0.8(0)$. Performance sensitive compensation (stock, options, bonus) accounts for about $43 \%$ of the total target compensation of the average executive in our sample, while salary accounts for about 57\%. More than one-third of CEOs have a MBA degree. They are

\footnotetext{
${ }^{10}$ Graham et al. (2005) obtain a response rate of 10 percent, Trahan and Gitman (1995) 12 percent, Graham and Harvey (2001) 9 percent, and Brav et al. (2005) 16 percent. In addition, Slemrod and Venkatesh (2002) survey tax preparers (12 percent response rate) and corporate taxpayers (9 percent response rate) about compliance costs. The referenced quarterly CFO survey can be found at http://www.cfosurvey.org.

${ }^{11}$ http://spccapital.com/FAQS.1.6-1.htm\#FAQ12
} 
predominantly male (92.3\%, not shown in table). In terms of career path, $16 \%$ of the sample comes from a finance/accounting career background. The average chief executive is 54 years old and has been in his or her current job for 10.4 years.

Table II reports the correlations between both firm and executive characteristics for the U.S. CEOs and their companies. Larger firms have more operating segments, compensate with proportionally more incentive pay, and have CEOs with shorter job tenure. CEOs with MBAs are younger, tend to have a career path in finance or accounting, and tend to have shorter tenures.

\section{What decisions rules are used to allocate capital across divisions?}

We analyze which decision rules companies use to internally allocate capital to divisions. Textbooks (e.g., Brealey, Myers, and Allen, 2010) propose that projects should be ranked by their net present value (NPV) contribution and capital should be allocated in recognition of this ranking. Anecdotal evidence implies that ad hoc decision rules are also used, such as the personal reputation of a divisional manager, internal company politics, or the CEO's gut feeling. In this section, we analyze which of these decision rules are most important.

\subsection{Capital allocation decision rules}

We ask CEOs which rules they use when deciding how to allocate capital across divisions within their firms. The most important factor that affects capital allocation decisions among the U.S. firms in our CEO sample is the NPV ranking (see Figure 1 and Table III, Panel A). ${ }^{12}$ The NPV criterion has a mean rating of 3.9 on a scale of 1 to 5 (with 5 indicating that the

\footnotetext{
12 Separately, we examine just the CEOs who answered 1, 2, or 3 on a scale of 1 to 7 regarding how much they delegate capital allocation decision authority (where 7 indicates complete delegation). The relative pattern of responses for the NPV Rank rule, as well as the other important factors affecting capital allocation, is not affected by the degree of delegation. We study the delegation of decision authority more thoroughly in Section 5.2.
} 
criterion is very important and 1 indicating not at all important). Nearly 79\% of U.S. CEOs say that NPV rankings are important or very important (i.e., a rating of 4 or 5) when deciding how to allocate capital. U.S. CFOs also list NPV rank as the most common criterion affecting capital allocation, as do executives outside the U.S. (see Figure 2). ${ }^{13}$

This finding is reassuring given that textbooks recommend the NPV ranking approach. It is important to interpret this result within the context of our sample. Recall that $88 \%$ of our U.S. sample is composed of private firms and note that Graham and Harvey (2001) find that net present value is used to make capital budgeting decisions in nearly $80 \%$ of U.S. public firms. Combined with our analysis, the evidence implies that the NPV capital allocation criterion pervades corporate decision-making around the world.

The second most important factor affecting capital allocation in the United States is the reputation of the divisional manager. More than $71 \%$ of U.S. CEOs rely on divisional manager reputation (mean rating of 3.80 out of 5) when deciding which division to allocate capital to, and 66\% of U.S. CFOs do so as well. In addition to being consistent with Prediction 7 implications from Dessein (2007), Stein (2003) and Ozbas (2005), common sense suggests that it is reasonable to allocate to divisional managers who have earned a reputation for delivering on past projects. Though this finding is not directly about decision authority, if decision rights accompany increased funding (and Jennergren (1981) argues they do), then our results imply that decision authority of lower level executives and managers increases with reputation.

These empirical results are consistent with Ross's (1986) analysis of 12 firms, which indicates that a divisional manager's investment projects are more often approved when she has delivered larger returns in the past. Bower (1970) also cites field evidence that headquarters is

\footnotetext{
${ }^{13}$ Due to the similarity of many results for foreign firms, we do not separately discuss the U.S. versus foreign comparison again until the end of this section.
} 
more likely to accept the ideas proposed by managers who have developed a reputation for delivering in the past. Our reputation result is consistent with the finding in Glaser et al. (2009) that powerful or connected managers receive a disproportionate share of cash windfalls in their detailed analysis of a single multinational conglomerate. One difference from our analysis is that their finding is tied to cash windfalls while we detect a reputational effect in normal capital allocation. Our finding is also related to Cremer et al.'s (2009) result that among banks that are members of a group, the members with the most influence (ratio of voting rights to ownership rights) are allocated more capital from headquarters. Our result differs in that our reputational effect does not vary with informational asymmetry (not shown in a table), while these authors interpret their result as being stronger as informational asymmetry rises.

When we ask directly about whether the past return on investments in a given division (instead of its manger's reputation) affects its future capital allocation, we find somewhat weaker support among U.S. CEOs (51\% list past divisional return as an important criterion in allocating capital), though support among U.S. CFOs is strong (about 64\%). This relative support implies that CEOs focus more on the individual manager involved, rather than on the division the manager represents, while CFOs focus more evenly on the individual and the division. Interestingly, CEOs with a finance background appear to take a more "numbers" approach by rating divisional return equal to managerial reputation. In contrast, CEOs with a non-finance background follow the "softer" approach of rating manager reputation (3.81) much higher than past divisional returns (3.48; not shown in table).

When presenting their capital allocation requests to headquarters, divisional managers convey their degree of confidence about whether a project will succeed. We interpret "confidence" to indicate the "tightness of the distribution" expressed about a given project, 
above and beyond the return that the project is expected to earn. Divisional manager confidence has great influence on corporate capital allocation decisions: 69\% of CEOs list this factor as being important in capital allocation within U.S. firms. We find this result interesting because we interpret it as indicating that that the second moment of information affects capital allocation decisions. Fewer CFOs than CEOs list divisional managerial confidence as being important (significantly fewer, as indicated by the $* *$ next to the $62.2 \%$ in the U.S. CFO column).

We inquire whether executives consider the timing of cash flows as they allocate capital within their companies. Being overly concerned about cash flow timing might indicate a "payback" type of thinking that is generally discouraged in textbooks. ${ }^{14}$ Nearly two-thirds of U.S. CEOs cite cash flow timing as an important capital allocation factor, as do a similar percentage of CFOs. We note that cash flow timing can rationally play a role if a firm is financially constrained, to the extent that it would be beneficial to accelerate cash flow receipt in certain states of the world.

We investigate whether financial constraints might be related to the importance of cash flow timing. Initially we do not find supporting evidence, given that the importance of timing is not related to past or expected growth or the size of the firm (not shown in table), variables that are sometimes used to proxy for financial constraint. In a separate question, we explicitly ask whether the need for external funding affects which divisional projects are allocated capital. This might be relevant if the firm is financially constrained. About $44 \%$ of the executives list the need for external funds as an important factor affecting capital allocation. The analysis is more intriguing when we interact the "internal/external financing" factor with the "cash flow timing"

\footnotetext{
${ }^{14}$ It is worth noting that Bernardo, Cai, and Luo (2001) argue that a payback approach is rational, in their case because it is harder to get managers to be honest about investment prospects as the horizon of the project increases (because it is harder to compare managerial forecasts to eventual outcomes). Therefore, a company might use payback to effectively heavily discount distant cash flows. McDonald (1998) notes that a payback rule of thumb can approximate optimal decision rules that account for option-like features of many investments.
} 
factor. We accomplish this by subsetting the sample and studying only the firms that rate external financing concerns as 4 or 5 (i.e., firms that might be financially constrained). For this subsample, we find that $79.5 \%$ of these firms rate cash flow timing as being important (see panel B of Table III). This $79.5 \%$ is statistically larger than the $56 \%$ of unconstrained firms that rate cash flow timing as important (the $56 \%$ is not shown in the table). Therefore, this evidence is consistent with the importance of cash flow timing being explained at least in part by the degree of financial constraint a firm faces.

Approximately half of CEOs list their "gut feel" as being important in deciding how to allocate capital across divisions. We find this response to be very interesting because it highlights the subjective nature of corporate investment and (perhaps) of decision making more generally. We also note that while in some cases it may be possible that surveyed executives "tell the professors what they want to hear" (for example, when indicating that net present value ranking determines capital allocation), this same bias in unlikely when executives indicate that gut feel affects corporate decisions. If anything, one would expect the rate of response to this question to be biased downward. We note that significantly more CEOs of small firms rely on their gut feel to make decisions (49\% of small firm CEOs rely on gut feel, versus $38 \%$ of large firms; not shown in table). The popularity of "gut feel" is consistent with the old adage that running a firm is "as much art as it is science."

We inquire whether corporate politics affect capital allocation decisions. Only one-in-ten U.S. CEOs indicates that politics matter (see Table III). Given that one would think that the top decision-maker might be the last person to admit that politics affect corporate decisions, this would suggest that the responses to this question represent a lower bound. This conjecture is bolstered by noting that CFOs are significantly more likely than CEOs to indicate that politics 
affect corporate decision-making: nearly one-in-four CFOs say that corporate politics affect capital allocation decisions.

Finally, among U.S. CEOs and CFOs, about $6 \%$ to $7 \%$ say that their company attempts to balance capital allocation evenly across divisions (which could be thought of as "corporate socialism"). Though the absolute level is low, untabulated analysis indicates that socialism is relatively more common when incentive compensation is not that important. This relative result is consistent with Ozbas and Scharfstein's (2009) and Palia's (1998) findings that socialism decreases with equity stakes and performance pay. Scharfstein and Stein's (2000) agency model can explain these findings if CEO incentive compensation counteracts the CEO impulse to allocate capital to managers of weak divisions in order to retain them. Ozbas and Selvili (2006) argue that rigid capital allocation (one possible manifestation of socialism) is more likely to occur when information asymmetry between the CEO and managers is high and as firms become more complex. Untabulated analysis indicates that surveyed growth firms are more likely to balance capital across divisions, but it does not support the implications that socialism increases with firm complexity or information asymmetry.

For the most part, the responses from foreign executives are similar to those for U.S. firms. We highlight two differences. First, relative to U.S. companies, a significantly higher proportion of foreign executives acknowledge that corporate politics affect capital allocation in their firms. In Table III, 18\% of European and Asian CEOs say that internal politics affect the distribution of funds across divisions, and 36\% of foreign CFOs say the same. Second, foreign companies are also more likely to strive to balance capital allocation across divisions. Nearly one in seven (five) foreign CEOs (CFOs) say that balanced allocation is important. ${ }^{15}$ Given that

\footnotetext{
${ }^{15}$ One possible explanation for the higher acknowledgement of corporate socialism in Europe, relative to the U.S., could be that European countries are generally more socialistic, and hence their executives could be more likely to
} 
European and Asian executives receive less incentive pay than do U.S. executives, the increased socialism in foreign firms is consistent with the Ozbas and Scharfstein (2009), Palia (1998), and Scharfstein and Stein (2000) implications mentioned above.

Table IV presents pairwise correlations for the responses to the various capital allocation factors. One interesting result is that CEOs who rely on the NPV rule to allocate capital are also likely to consider divisional manager reputation (correlation coefficient of 35\%) but they are less likely to participate in corporate socialism (-4\%).

\section{Delegation of the corporate decision-making process}

The previous section examines how capital is allocated within a company to fund projects. In this section we examine how decision authority more generally is shared. We start in Section 5.1 by examining the degree to which various decisions are shared. To our knowledge ours is the first paper to document the degree of CEO dominance of these corporate policies. In Section 5.2 we examine the firm and executive characteristics that are associated with more delegation.

\subsection{Which corporate policies do CEOs delegate?}

To gauge how decision authority is shared, we ask the following question for five different policies: "Amongst the management team, who has the most input in the following policies?" We study policies related to capital structure, payout, capital investment, allocating capital across divisions, and mergers and acquisitions. Managers are asked to respond on a scale of 1-7, where 1 is "I make decision without help from others," and 7 stands for "Others make the

answer survey questions accordingly, even if perhaps their firms are not actually more socialistic in practice. To investigate this possibility, we examine the propensity to acknowledge corporate socialism on the survey separately for each European country in our sample. We do not find any evidence that CEOs of companies headquartered in more socialistic European countries are more likely to respond that their firms are more likely to participate in corporate socialism as measured on our survey. 
decision." Thus, a 7 indicates that the CEO delegates a corporate decision completely to other executives or managers, while a 1 indicates that the executive makes the decision more or less on his/her own, with no delegation.

We first examine how often CEOs consider themselves to be the sole decision-maker (i.e., a response of 1 out of 7) for a given corporate policy, and we compare this information to the views reported by CFOs regarding their role in the decision process. We start by analyzing the responses of the roughly 950 CEOs and 525 CFOs who work at U.S. based firms and who answered these questions. Figure 3 (panel A) and Table V present the analysis. Figure 3, panel B compares the U.S. responses to those from Asia and Europe.

Not surprisingly, CEOs more often claim to be the sole decision makers relative to CFOs' views of their own roles in the decision process, though we document for the first time the magnitude of these views. CEOs tell us that they are most influential (i.e., most likely to make decisions without input from others) in merger and acquisition decisions (15.4\% of U.S. CEOs assign a rank of 1 to their input, thereby claiming to make the M\&A decision in isolation) and capital structure decisions (15.1\%). This dominant role of CEOs in acquisitions is consistent with Prediction 6. This hypothesis flows from Harris and Ravis (2005), who argue that the acquisition decision is one policy that should not be delegated to lower-level managers. Similarly, Aghion and Tirole (1997) argue that projects with long-term and external effects (like mergers) are less likely to be delegated.

In decreasing order of CEO influence, $13.7 \%$ of chief executives claim to dominate payout, capital allocation (13.4\%), and investment (10.6\%) decisions. Three percent of CFOs indicate that they have sole influence in capital structure, the highest among the corporate 
decisions that we examine. This number is a significantly lower proportion than for CEOs (as indicated by the $* * *$ next to the $3.1 \%$ in Panel A or Table V).

As a corollary, we examine how often CEOs say that they make a given corporate decision with very little or no input from others (i.e., a response of 2 or 1), and again compare to the decision-making authority of CFOs. These results are shown in panel B of Table V, and are similar to those in panel A discussed above, though the magnitudes are much larger. For example, $46.5 \%$ of CEOs rate their dominance of the merger and acquisition decision as a 1 or 2 , compared to about $10 \%$ for CFOs. CFOs play a large role in capital structure decisions (relative to CFO importance in other decisions), where one-in-four say they make the decision with little or no input from others. Though not shown in the table, the results in Table $\mathrm{V}$ hold in smaller samples in which we match each CEO firm to a CFO firm based on whether the firm is public or private, and separately based on sales revenue matching.

Panels $\mathrm{C}$ and $\mathrm{D}$ of Table $\mathrm{V}$ show which decisions CEOs are more likely to delegate. A choice of 7 indicates complete delegation (Panel C), while choosing 6 or 7 indicates nearly complete delegation (panel D). CEOs indicate that they are most likely to completely delegate capital structure decisions, and least likely to completely delegate investment decisions. Finally, looking across all the panels, investment decisions appear to be the most equally shared corporate decision (not dominated by CEOs and not dominated by CFOs).

\subsection{Under what circumstances are corporate decisions delegated by the CEO?}

In this section, we investigate the conditions under which decision-making authority is shared. We estimate five regression equations (one each for capital structure, corporate investment, capital allocation, payout, and mergers and acquisitions), with all five estimated in a 
single system and standard errors clustered by CEO. For expositional ease, we describe the experimental design for capital structure decisions, though this set up applies similarly to the other corporate policies.

We use an ordered logit regression to explore the circumstances that lead to delegation by the CEO. The dependent variable is derived from the degree of delegation. The raw data take on integer values between 1 and 7, with 7 indicating complete delegation of a decision to employees below the level of CEO. To construct the dependent variable for the regression, we divide the degree of delegation into 3 buckets: 0 (if the respondent answered 1 or 2), 1 (if the respondent answered 3 or 4 ), and 2 (if the respondent answered 5, 6, or 7). The right hand side variables capture firm and CEO characteristics. The theoretical predictions in Section 2 suggest signs for some of the estimated coefficients. We interpret the coefficient signs as suggestive evidence with respect to predictions generated from theory, but not as rigorous tests of causality or direct tests of any one underlying theory. Estimation results are presented in Table VI.

The first prediction is that the delegation of decision-making authority increases when the CEO is overloaded in the sense of there being (too) many decisions to make. We measure this effect based on firm size and the number of business segments (e.g., divisions) in the company. The positive coefficient in Panel A of Table VI indicates that CEOs in firms with more business segments are significantly more likely to share/delegate capital structure decision authority with/to employees lower down the company. The estimated ordered logit coefficient of 0.676 in column 1 indicates that as a firm changes from two or fewer segments to more than two segments, the odds of being in a higher bucket (representing more delegation) roughly doubles. That is, the odds of moving from the " 0 " delegation bucket to the " 1 " bucket", or the " 1 " bucket 
to the " 2 " bucket, increases by $96.60 \%$ (not shown in table ${ }^{16}$ ) while the other variables in the model are held constant. The estimated coefficient on the size variable is also positive, again consistent with capital structure decisions being delegated or shared as the magnitude of the firm's operations increases. ${ }^{17}$ The estimated coefficient indicates that as a firm grows in size (goes from small to large), the odds of being in a higher bucket increases by $158.83 \%$ (not in table), holding the other variables in the model constant.

Table VI, Panel B presents the regression coefficients for all five policies. To save space, only the results analogous to columns 1, 6, and 7 of Panel A are presented in Panel B (complete information is available upon request). The results are consistent with those discussed so far. The positive signs on the business segment and firm size variables are consistent with Prediction 1 , indicating that decision authority is more likely to be shared or delegated as a company grows larger, and more complex, and the CEO's workload in turn increases. These results are consistent with the theoretical implications in Aghion and Tirole (1997) that overloaded CEOs delegate decisions down the corporate ladder.

The results discussed so far implicitly assume that the degree of delegation is assigned separately for each corporate policy. Alternatively, it may be the case that the tendency to delegate is more general, applying to all policies within a given company. To investigate this latter case (that is, to study delegation as a company-wide phenomenon), we repeat the regression but in Table VII we constrain the estimated coefficients for a given explanatory variable to be identical for all five policies. When we do this, the estimated coefficients and significance are similar to that in Table VI and supportive of Prediction 1. Overall, the second to

\footnotetext{
${ }^{16}$ In column (7) of Table VI, Panel A, the change in odds ratios are presented for coefficients estimated in Column (6). To save space, the change in odds ratios are not presented for coefficients in Column (1) to Column (5).

${ }^{17} \mathrm{Li}$, Minnis, Nagar, and Rajan (2009) find that CEOs of large firms talk less on earnings conference calls (their measure of increased delegation).
} 
last row in Table VII indicates that the unconstrained coefficients in Table VI are in general not significantly different (at a 5\% level) from the constrained coefficients in Table VII. This result is consistent with the effect of firm and executive characteristics on delegation being a companywide phenomenon.

Another interesting finding generally consistent with Prediction 1 is that CEOs of firms that have made two or more acquisitions in the past two years (i.e., the "multiple acquisitions" variable in Column 6 of Table VI) are more likely to share decision authority in capital structure and capital allocation decisions. This result is consistent with the common view that executives of acquiring firms spend a disproportionate amount of their time integrating new business units into their firms. Therefore, it makes sense that these same executives are more likely to delegate other corporate decisions. It is also worth noting that CEOs are not inclined to share the merger and acquisition decision itself, even when their firm has recently made multiple acquisitions (the multiple acquisitions coefficient is insignificant in the M\&A columns of Panel B). This is consistent with the unconditional evidence in Table V that CEOs say that they are the dominant merger and acquisition decision-maker.

Prediction 2 is that delegation of decision-making authority decreases with the level or importance of the CEO's private knowledge. We use the CEO's tenure as chief executive to measure her knowledge. The negative estimated coefficient on CEO tenure in the first column of Table VIA is consistent with the prediction that as the CEO becomes more knowledgeable she is less likely to share the capital structure decision with others. ${ }^{18}$ The -0.556 estimated coefficient implies that as a CEO's tenure grows longer (goes from short to long), the odds of being in a

\footnotetext{
${ }^{18}$ Baiman et al. (1995) measure CEO expertise as being high with respect to a business unit when the overall corporation's 2-digit SIC code is the same as that for a given business unit (and expertise is low when the unit has a different SIC code than the corporation). They find that business units are more likely to have control over core functions (that is, core functions are delegated to the units) when CEO expertise is low (that is, when the unit is in a different SIC code than the corporation).
} 
higher delegation bucket decrease by $42.65 \%$ (not shown in table), holding other variables constant. The reluctance to share decision authority with others as tenure increases is also evident in acquisition, payout, and investment decisions. Tenure is also significantly negatively related to delegation in Table VII, which as mentioned before considers company-wide delegation by constraining the estimated parameter to be equal across all five policies. This tenure result is interesting because an alternative hypothesis is that CEOs delegate more as time passes and they become more comfortable with their employees. We find the opposite. When we split the tenure variable into several separate dummy variables measuring length of time on the job, we find generally that the tendency to delegate grows weaker as length of career grows longer (i.e., delegate less as tenure increases; not shown in table), consistent with tenure capturing the knowledge-based incentive to delegate less.

Separately, we consider CEO age (the variable "Old") as a measure of knowledge but find no statistical significance consistent with Prediction 2 for any corporate policy. Nor do we find evidence that a finance or accounting career path affects CEO delegation in Table VI. However, there is evidence in Table VII that having a finance career (and presumably more related knowledge) leads to less delegation across the five financial policies considered jointly. ${ }^{19}$

The variable indicating whether the CEO has an MBA degree can also be interpreted as identifying chief executives who have private or valuable knowledge (assuming that a Masters of Business Administration degree enables CEOs to better process or interpret information). The MBA coefficient is significantly negative, indicating less delegation, in the capital allocation and investment decisions (see Table VIB) and in Table VII. ${ }^{20}$ These results are consistent with

\footnotetext{
${ }^{19}$ Xuan (2009) documents "reverse favoritism" in which new CEO's allocate relatively more capital to divisions other than the one(s) in which they previously worked.

${ }^{20}$ It is interesting to note that the negative estimated coefficient is counter to the idea that the "teamwork" training that MBAs receive in business school leads to more delegation or sharing of decision authority.
} 
Prediction 2 that as a CEO becomes more knowledgeable, she is less inclined to delegate decision authority. However, the MBA result is weak statistically.

The third prediction is that corporate decision-making authority is more likely to be delegated in uncertain environments. We attempt to capture uncertainty based on dummy variables that indicate when a firm is in the high-technology industry (high uncertainty) or manufacturing industry (low uncertainty). Table VI, Panel B indicates that there is more delegation in the tech industry in three of the five policies (capital structure, capital allocation, capital investment); however, the relation is statistically significant only for capital allocation (and only in specifications not shown in Table VI, panel B). Therefore, the evidence in support of Prediction 3 is at best weak, though this may be because our measure of uncertainty is weak. ${ }^{21}$

Prediction 4 relates the delegation of decision-making authority with the degree to which employees are paid with incentive compensation. Aghion and Tirole (1997), Prendergast (2002), and Van den Steen (2010) link delegation to employee incentive compensation. Unfortunately, we do not have information on the degree to which employees are paid with incentive compensation. We survey CEOs and CFOs and ask about their own incentive compensation but we do not ask about variable compensation for other employees in their firms. If the target proportion of executive remuneration that is constituted by incentive pay is a good proxy for a similar measure for lower-level employees, Prediction 4 anticipates a positive correlation between variable compensation and delegation. However, if executive variable pay itself has an opposite effect, providing incentive for the executive to retain control of the decision and not delegate, we might find a negative relation. The estimated variable pay coefficient is negative in all the specifications, consistent with the latter interpretation. However, the evidence is weak

\footnotetext{
${ }^{21}$ Nagar (2002) measures uncertainty based on the standard deviation of return on assets. He finds that bank branch manager discretion increases with uncertainty (and also with incentive compensation, which we investigate next). In our sample, we do not find a relation between delegation and an industry-wide uncertainty measure like Nagar's.
} 
statistically and is significant only for payout (in a specification not shown in Table VIB) and capital allocation. When considering company-wide delegation in Table VII, we find that CEOs delegate less when they receive more variable compensation. The overall weakness of this relation could be because of the offsetting theoretical predictions or because of noisiness in variable measurement.

The fifth prediction is that delegation of decision-making authority decreases with the growth opportunities of the firm. This prediction is based on a theoretical implication from Taggart (1987) and Marino and Matsusaka (2005) that headquarters is more likely to retain control when a firm has unexercised growth options. As our measure of growth opportunities, we use the self-declared expected growth of the firm (sales growth over the next three years). The sign on the variable indicating expected growth is negative as expected in the capital structure, merger and acquisition, payout, and capital allocation decisions. However, it is only consistently significant in the capital structure and merger specifications. The -0.428 estimated coefficient in Column 1 of the capital structure specification indicates that as a firm's expected growth increases (goes from low to high expected growth, with median growth as the breakpoint), the odds of being in a higher delegation bucket decrease by $34.82 \%$ (not in table), all else constant.

Overall, our analysis detects several factors that are associated with delegation of decision-making authority within the firm. In particular, we find evidence that delegation is more likely to occur when 1) the CEO's workload is high, as measured by number of business segments and firm size, and less likely when 2) the CEO's knowledge is particularly valuable as measured by CEO tenure. We find weaker evidence that delegation decreases when 3) the CEO is compensated with variable pay, 4) the CEO has an MBA, 5) the company has growth options, 
6) the chief executive has a finance or accounting background, and 7) the firm has not been involved in many recent acquisitions.

There are important considerations one should keep in mind when interpreting our results. First, our sample is composed predominantly of private firms. This has the advantage of providing new information about an important part of the economy. The public/private dummy variable is for the most part not significant in Table VI (suggesting that our results generally would hold for public firms). It is significant in the Table VII specification, providing some evidence that public firms may delegate more (perhaps due to the extra demands and regulatory requirements of public firm CEOs). Unfortunately, we do not have enough public observations to test whether our results hold on a public only sample. Second, our variables as defined do not align perfectly with the modeling environment underlying the theoretical predictions. Therefore, regression evidence consistent or inconsistent with any theory should be interpreted as suggestive but not as definitive. We hope that our analysis leads to future research that is tailored specifically to test a given theory. Third, we used a "low, medium, high" dependent variable. If we alternatively delete the "medium" observations (by using a binary variable that compares CEOs who chose $1 / 2$ versus $5 / 6 / 7$ on the seven point scale, ignoring those that chose 3 or 4 ), the results are a little stronger. ${ }^{22}$

We examine specifications that apply if one's prior is that delegation varies by policy (Table VI) and also specifications that are relevant if one's prior is that delegation is pervasive across all policies and varies only by firm or CEO characteristic (Table VII). Given the similarity

\footnotetext{
22 For example, in column (2) of Table VII, the estimated coefficients (t-statistics) are 0.660 (2.96), 1.42 (4.01), 0.639 (2.88), -0.485 (2.08), and -0.10 (2.40).
} 
of the findings in the two tables, the latter interpretation seems plausible. ${ }^{23}$ Finally, as mentioned above, our data are based on self-declared responses to a survey. We look forward to future research based on different data sources that further investigate the issues raised here.

\section{Conclusions}

We survey more than 1,000 CEOs and CFOs in the United States, Europe, and Asia to provide empirical evidence about how capital is allocated within firms and under what circumstances decision-making authority is delegated to lower level managers. Our evidence partially supports theoretical predictions that CEOs delegate more when they are overloaded, less when their knowledge is particularly valuable, and (weakly) when growth options and CEO incentive pay are low. We also report that CEOs claim to dominate (that is, do not delegate) merger and acquisition decisions. While CEOs also dominate other decisions, they are relatively more likely to delegate at least part of these decisions to employees or committees.

We study capital allocation in detail. As promoted in finance textbooks, CEOs rely heavily on the NPV ranking of various projects. We also find that capital allocation is affected by the divisional manager's reputation, the timing of when cash flows are produced by a project, and senior management's "gut feel." Finally, we find that, relative to U.S. firms, in foreign companies capital is more likely to be evenly distributed across divisions, and corporate politics are more likely to play an important role.

\footnotetext{
${ }^{23}$ Moers (2006) finds that delegation seems to be linked across the five policies he examines (the development of new products, hiring and firing, selection of investments, budgeting, and pricing decisions), though he does not test this link statistically.
} 


\section{Appendix - Survey design and delivery}

We created an initial survey instrument based on existing theoretical and empirical research. We then solicited feedback from a number of academics, practitioners, and CEOs on the initial version of the survey. Based on this feedback, we shortened and focused. We also sought and incorporated the advice of marketing research experts on the survey's design and execution. A PDF of the faxed English language version of the final survey instrument can be found at http://faculty.fuqua.duke.edu/ jgraham/CEOCFO.pdf For most of the participants, rather than a fax, the version of the survey they were administered consisted of a series of linked HTML pages.

We surveyed both CEOs and CFOs. We contacted three groups of CEOs. The largest group was approximately 10,000 executives who subscribe to Chief Executive magazine. Chief Executive has more than 70,000 subscribers, and we emailed an invitation to participate in the survey to the CEO subscribers who work at the largest 10,000 companies (among their 70,000 subscribers). There was a bounceback rate of about 2.3 percent on the emails, meaning that as many as 9,770 executives could have received the invitation (though email filters or other barriers likely reduced the number of executives who actually saw the survey). We also reached out to readers of Chief Executive with an advertisement in the magazine that invited them to go to a weblink to participate in the experiment. This printed advertisement attracted fewer than two dozen participants, and if we were to delete these CEOs from the sample our results do not change. Due to their small number, we do not separate out these CEOs in the analysis but instead merge them in with the other Chief Executive respondents.

The second group of CEOs we contacted are 800 (net of bounced emails) chief executive readers of $C F O$ magazine. We emailed the same survey invitation to these executives. The third group of CEOs attended the World Economic Summit in Davos during January 2006. We faxed surveys to 142 Davos' executives and received seven responses. If we were to delete these responses, it would not alter our results. Due to their small number, we do not separate out these CEOs in the analysis.

In total, we surveyed approximately 10,700 CEOs, once improper email addresses are eliminated. All of these invitations were issued on approximately February 1, 2006. We sent a reminder to all those emailed on Feburary $14^{\text {th }}$. Across all these groups, 1,180 CEOs responded, for a response rate of approximately $11 \%$. In the analysis, we focus primarily on the 1,017 CEOs who work for firms headquartered in the United States.

During the first two weeks of February 2006, we also invited four groups of U.S. CFOs to participate. ${ }^{24}$ The largest group of surveyed CFOs consists of subscribers to $C F O$ magazine. On our behalf, the magazine emailed 6,800 invitations (net of bounced emails) to subscribers of the U.S. version of its primary publication, $C F O$ magazine. Separately, Duke University emailed 2,000 (net of bounced emails) CFOs who had participated in previous quarterly CFO Global Business Outlook surveys conducted by researchers at Duke and $C F O$ (see http://www.cfosurvey.org). The response rate for the quarterly survey is typically 5 to 6 percent. The third group was 253 CFOs who participate in the Forum on Corporate Finance. Finally, 107 financial officers who are alumni of Duke University were faxed a survey instrument (the results

\footnotetext{
${ }^{24}$ Most of those surveyed have the job title CFO. Some have the title of Treasurer, Assistant Treasurer, VP Finance, Comptroller, or a similar title. We refer to this group collectively as CFOs.
} 
do not change if the faxed responses are ignored). All total, approximately 9,000 U.S.-based CFOs were surveyed. We received 549 responses, for a response rate of approximately 6\%.

We also surveyed Asian and European chief financial officers. In particular, we invited subscribers to $C F O$ Europe and $C F O$ Asia magazines to participate. In the demographic questions, we verify that these respondents in fact work in firms that are headquartered in these geographic regions. $C F O$ Europe sent approximately 5,600 email invitations and $C F O$ Asia 4,500, both figures net of emails that bounced. Nearly 400 European CFOs responded, as did 264 Asian CFOs, yielding response rates of approximately $7 \%$ and $6 \%$, respectively. The Asian group was not sent an email reminder because the reminder date fell near the Chinese New Year. The European response rate may be a little higher because we gave the executives the opportunity to take the survey in any of four languages: English, French, German, or Dutch. The Asian survey was only available in English. In the analysis, the non-US executives and CFOs are primarily included as a comparison group to the U.S. analysis.

It is important to understand the population that our surveyed firms represent. We do not know the demographic information of the universe of surveyed firms. Therefore, in addition to describing the companies in our sample (as in Tables I and II), we follow the recommendation by List (2007) who says that what is most relevant is to benchmark the sample under study to wellknown samples of firms. In our case, we benchmark to the frequently examined Comupstat database. We examine sales, debt-to-assets, and other variables as shown in Table A. Briefly, the sales comparison indicates that our sample firms are smaller than the typical Compustat firm, with two-fifths of our sample falling in the smallest Compustat quintile. This is not surprising given that $8 \%$ of our firms are private, and almost all firms on Compustat have publicly traded equity. The survey response sample is, however, fairly representative of the Compustat universe in terms of debt/assets and historical growth (except that we have very few firms from the lowest growth quintile). We repeat this analysis in Panel B, examining only the 90 public firms in our sample that are managed by U.S. CEO's. The distribution of sales revenue for our public firms is roughly centered on the distribution of Compusat firms, with 58.5\% of our sample falling in Compusat quintiles 3 and 4 . Though not shown in the table, we separately compare our private firms to the private firms in the CapitalIQ database and find that they are similar to each other, though the sample private firms are somewhat larger. 


\section{References}

Acemoglu, D., Aghion, P., Lelarge, C., Van Reenen, J., and Zilibotti, F., 2007, Technology, Information and the Decentralization of the Firm, Quarterly Journal of Economics 122, 1758 - 99

Aggarwal, R. and A. Samwick. 2003. Performance Incentives within Firms: The Effect of Managerial Responsibility. The Journal of Finance 63(4): 1613-1649.

Aghion, P. and J. Tirole, 1997, Formal and Real Authority in Organizations, Journal of Political Economy 105, $1-29$.

Alonso, R., Dessein, W. and Matouschek, N., 2008, When Does Coordination Require Centralization?, American Economic Review 98(1), 145 - 179

Alonso, R. and Matouschek, N., 2007, Relational Delegation, RAND Journal of Economics 38 (4), 1070 - 1089

Baiman, Stanley, David Larcker, and Madhav Rajan, 1995, Organizational Design for Business Units, Journal of Accounting Research 33, 205-229.

Baker, G.,, Gibbons, R., and Murphy, K., 1999, Relational Contracts and the Theory of the Firm, Quarterly Journal of Economics 117, No. 1, 39 - 84

Bertrand, M., and A. Schoar, 2003, Managing with Style: The Effect of Managers on Corporate Policy, joint with Marianne Bertrand, The Quarterly Journal of Economics, 118 (4), 1169-1208.

Ben-David, Z., J. Graham, and C. Harvey, 2008, Managerial Overconfidence and Corporate Policies, Working Paper, Duke University.

Bloom, N., Sadun, R., and Van Reenen, John, 2009, The Organization of Firms across Countries, Stanford Working Paper

Bower, Joseph, 1970, Managing the Resource Allocation Process. Harvard Business School Press, Cambridge, MA.

Colombo, M. and Delmastro, M., 2004, Delegation of Authority in Business Organizations: An Empirical Test, The Journal of Industrial Economics LII, 53 - 79

Grav, A., J. Graham, C. Harvey and R. Michaely 2005, Payout Policy in the 21st Century, Journal of Financial Economics 77, 483 - 527

Brealey, Myers, Allen, 2010, On Real Options, Journal of Applied Corporate Finance 20 No 4, 58 - 71

Chava, S. and Purnanandam, A., 2009, CEO vs CFOs: Incentives and Corporate Policies, Journal of Financial Economics 97(3), $303-488$

Cremers, M., R. Huang, and Z. Sautner, 2009, Internal Capital Markets and Corporate Politics in a Banking Group, Working Paper, Yale University.

Dessein, W., 2002, Authority and Communication in Organizations, The Review of Economic Studies 69, 811838.

Dessein, W., 2007, Why a Group Needs a Leader: Decision-making and Debate in Committees, Working Paper, University of Chicago.

Frank. M.Z., and V. Goyal, 2007, Corporate Leverage: How much do Managers Really Matter? Working Paper, University of Minnesota. 
Freeland, Robert F, 1996, The Myth of the M-Form? Governance, Consent and Organizational Change, The American Journal of Sociology 102(2), 483 - 526

Gibbons, R., 2009, Inside Organizations: Pricing, Policies and Path Dependence, Annual Review of Economics 2009

Glaser, M., F. Lopez de Silanes, and Z. Sautner, 2009, Opening the black box: Internal capital markets and managerial power in conglomerates, working Paper, University of Mannheim.

Graham, J. R., and C.R. Harvey, 2001, The Theory and Practice of Corporate Finance: Evidence from the Field. Journal of Financial Economics 60, 187-243.

Graham, J. R., C.R. Harvey and S. Rajgopal, 2005, The Economic Implications of Corporate Financial Reporting, Journal of Accounting and Economics 40, 3-73.

Graham, J. R.., C. R. Harvey, and M. Puri, 2010, Managerial Attitudes and Corporate Actions, Duke University Working Paper.

Harris, M., and A. Raviv, 2005, Allocation of Decision-making Authority, Review of Finance 9, 353-383.

Hart, Oliver, and Bengt Holmstrom, 2009, A Theory of Firm Scope, Quarterly Journal of Economics, forthcoming.

Hart, Oliver, and John Moore, 2005, On the Design of Hierarchies: Coordination versus Specialization, Journal of Political Economy 113, No. 4, 675 - 702.

Jennergren, L. P., 1981, Decentralization in organizations. In Nystrom, P. and Starbuck, W. (Eds.), Handbook of Organizational Design. Oxford University Press.

Li, Feng, Michael Minnis, Venky Nagar, and Madhav Rajan, 2009, Formal and Real Authority in Organizations: An Empirical Assessment, University of Michigan working paper.

List, John A., 2007, Field Experiments: A Bridge between Lab and Naturally-Occurring Data, NBER Working Paper.

Malmendier, U., and G. Tate, 2005, CEO Overconfidence and Corporate Investment, Journal of Finance, 60 (6), 2661-2700.

Malmendier, U., and G. Tate, 2008, Who Makes Acquisitions? CEO Overconfidence and the Market's Reaction, Journal of Financial Economics 89, 20 - 43

Marino, Anthony M., and John G. Matsusaka, Decision Processes, Agency Problems, and Information: An Economic Analysis of Capital Budgeting Procedures, Review of Financial Studies 18, 301-325.

McDonald, R.L., 1998. Real options and rules of thumb in capital budgeting. In: Brennan, M.J., Trigeorgis, L. (Eds.), Innovation, Infrastructure, and Strategic Options. Oxford University Press, London.

McNeil, C. and Smythe, 2009, T., Division Manager Lobbying Power and the Allocation of Capital, The Financial Review 44, $59-85$

Moers, F. 2006. Performance Measure Properties and Delegation. The Accounting Review 81(4): 897-924.

Mookherjee, Dilip, 2006, Decentralization, Hierarchies, and Incentives: A Mechanism Design Perspective, Journal of Economic Literature XLIV, 367 - 390 
Nagar, Venky, 2002, Delegation and Incentive Compensation, The Accounting Review 77, 379-395.

Ortega, J. 2009. Employee Discretion and Performance Pay. The Accounting Review 84(2): 589-612.

Ozbas, Oguzhan, 2005, Integration, Organizational Processes, and Allocation of Resources, Journal of Financial Economics 75, 201-242.

Ozbas, Oguzhan, and Zekiye Selvili, 2006, Organizational Scope and Allocation of Resources: Evndence on Rigid Capital Budgets, Working Paper, USC.

Ozbas, Oguzhan, and David Scharfstein, 2010, Evidence on the Dark Side of Internal Capital Markets, Review of Financial Studies 23(2), 581 - 599.

Palia, Darius, 1999, Corporate Governance and the Conglomerate Discount, Working Paper, Rutgers.

Prendergast, Canice, 2002, The Tenuous Trade-off between Risk and Incentives, Journal of Political Economy 110, 1071-1102.

Rajan, R. and J. Wulf, 2006, The Flattening Firm: Evidence from Panel Data on the Changing Nature of Corporate Hierarchies, The Review of Economics and Statistics 88, 759-773.

Rantakari, Heikki, 2008, Governing Adaptation, Review of Economic Studies 75, 1257 - 1285

Ross, M., 1986, "Capital Budgeting Practices of Twelve Large Manufacturers," Financial Management, 15, 1522.

Scharfstein, David and Jeremy Stein, 2000, The Dark Side of Internal Capital Markets: Divisional Rent-Seeking and Inefficient Investment, Journal of Finance 55, 2537-2564.

Slemrod, J. "Tax Effects on Foreign Direct Investment in the U.S.: Evidence from a Cross-Country

Comparison" in A. Razin and J. Slemrod (eds.), Taxation in the Global Economy (1990). University of Chicago Press.

Stein, Jeremy, 2003, Agency, Information, and Corporate Investment. In Constantindes, Harris, and Stulz (Eds.), Handbook of Economics and Finance, Elsevier.

Taggart, R., 1987, Allocating Capital Among a Firm's Divisions: Hurdle Rates vs. Budgets, Journal of Financial Research, 10, 177-190.

Trahan, E.A. and L.J. Gitman, 1995, "Bridging the Theory-Practice Gap in Corporate Finance. A Survey of Chief Financial Officers." Quarterly Review of Economics and Finance 35, 73-87

Van den Steen, Eric, 2004, Culture Clash: The Costs and Benefits of Homogeneity, MIT Working Paper.

Van den Steen, Eric, 2005, "Organizational Beliefs and Managerial Vision," Journal of Law, Economics and Organization, Oxford University Press, 21(1), 256-283.

Van den Steen, Eric, 2010, Interpersonal Authority in a Theory of the Firm, American Economic Review 100, 466-490.

Wulf, Julie, 2007, Authority, Risk, and Performance Incentives: Evidence from Division Manager Positions Inside Firms, The Journal of Industrial Economics LV, 169-196.

Xuan, Y., 2009, Empire-Building or Bridge-Building? Evidence from new CEOs' Internal Capital Allocation Decisions, Review of Financial Studies 22(12), 4919 - 4948. 


\section{Figure 1:}

\section{Capital Allocation Factors}

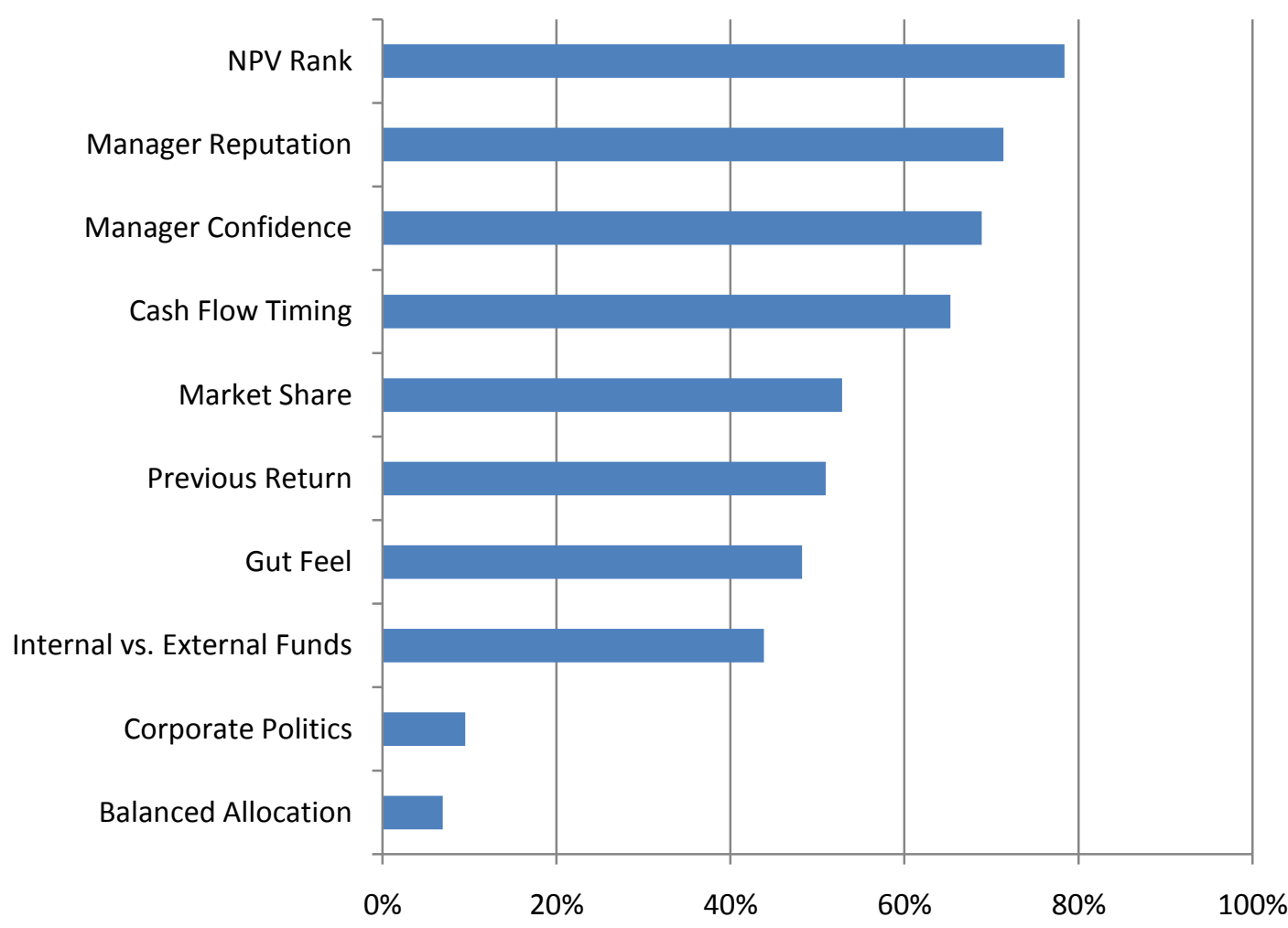

Percent of U.S. CEOs identifying factor as important or very important

Figure 1: Survey evidence on the factors that affect capital allocation decisions within a firm. The responses in this graph are for more than 1,000 U.S. CEOs. Respondents ranked the importance of each factor on a scale of 1 to 5 , with 1 being not important at all and 5 being very important. A factor is deemed to be "important" to a respondent if the ranking was a 4 or 5. 


\section{Figure 2:}

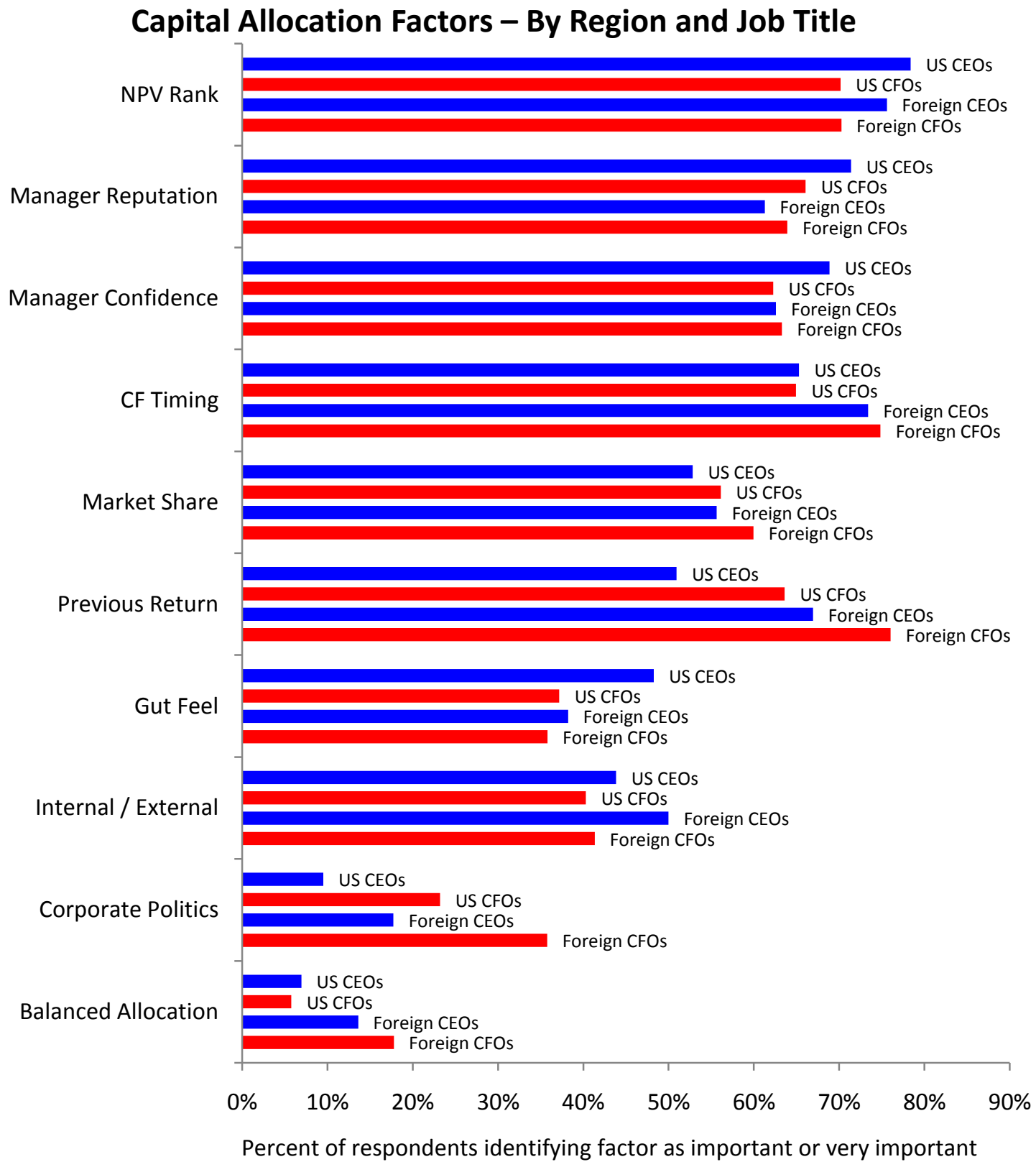

Figure 2: Percent of respondents identifying a factor as important or very important in making capital allocation decisions. Respondents ranked the importance of each factor on a scale of 1 to 5, with 1 being not important at all and 5 being very important. A factor is deemed to be "important" to a respondent if the ranking was a 4 or 5 . 
Figure 3:

Panel A: U.S. CEOs and CFOs involvement in decisions
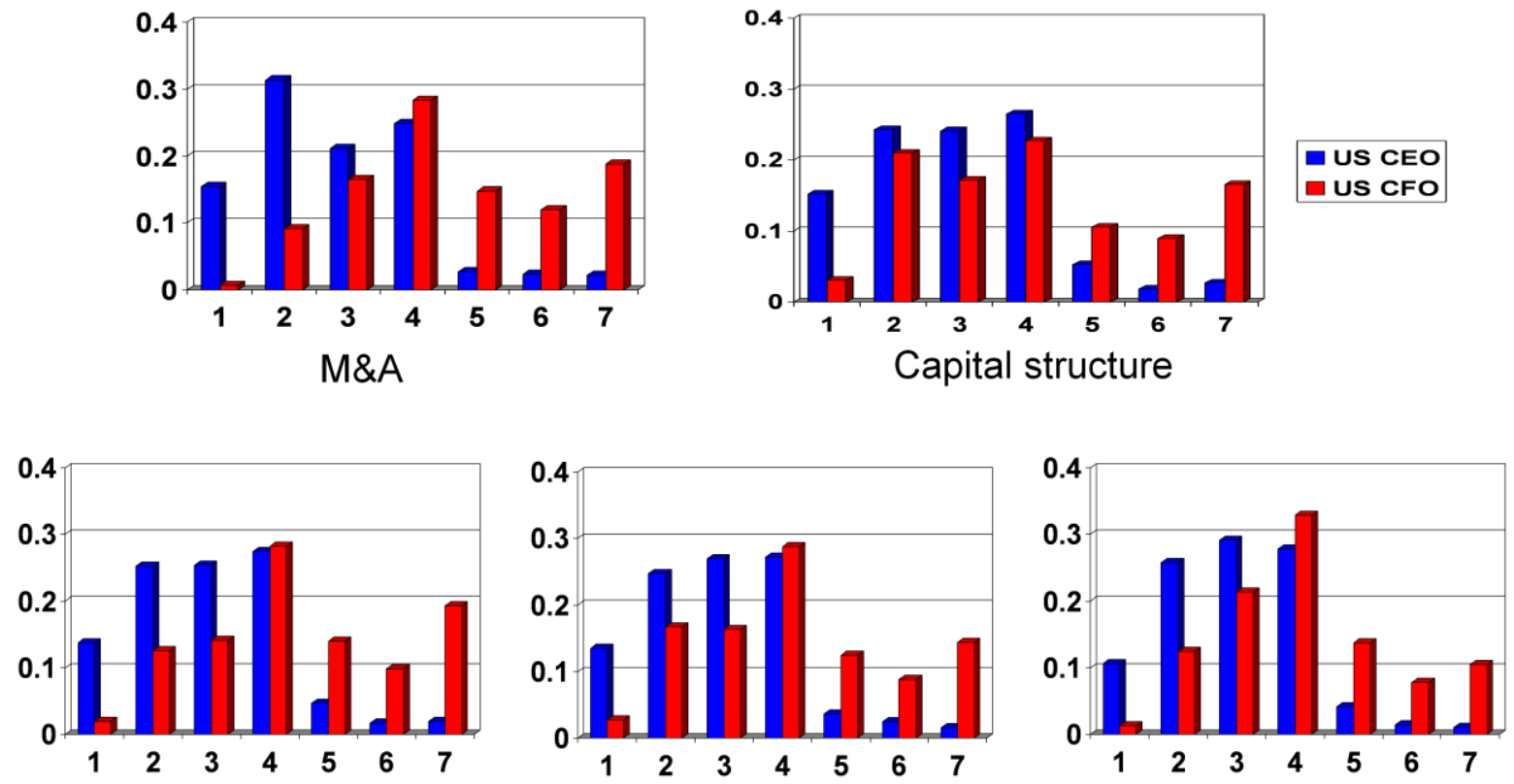

Payout

Capital allocation

Investment

Panel B: A Comparison of U.S. and Foreign CEO and CFOs' roles in decisions
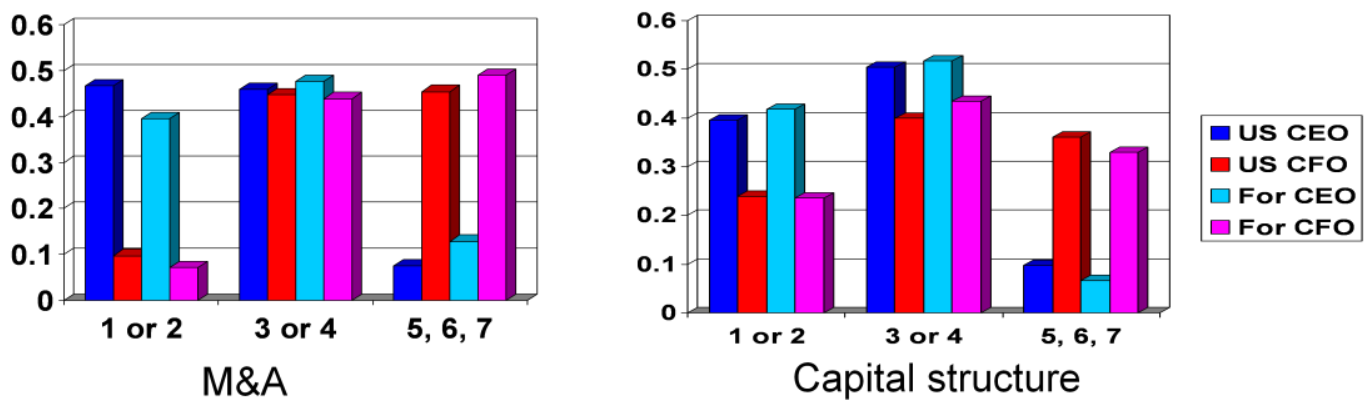

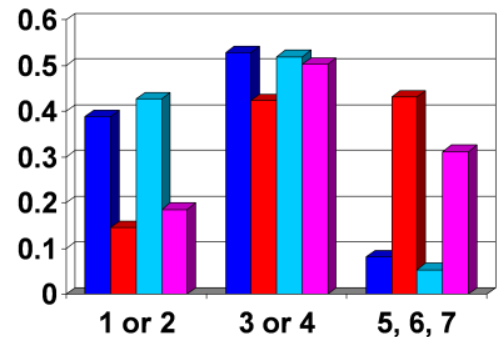

Payout

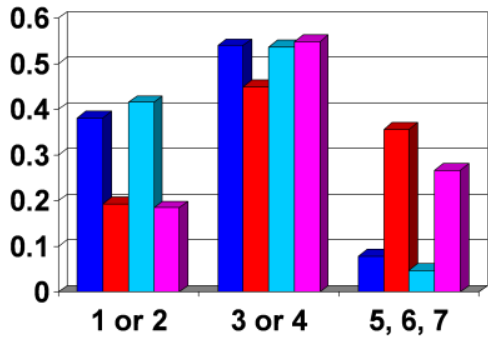

Capital allocation

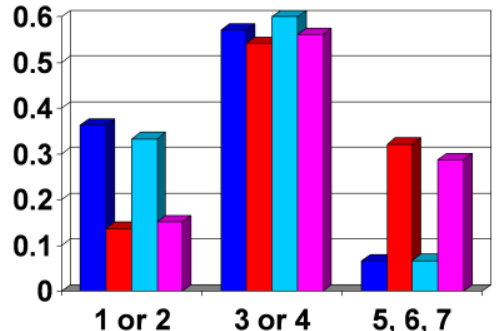

Investment

Figure 3: Panel A shows the degree to which US CEOs and CFOs describe their involvement in decisions about M\&A, capital structure, payout policy, capital allocation and capital investment. A response of ' 1 ' means that the respondent makes the decision solely by herself, while a response of ' 7 ' 
means that the decision is delegated to others with no involvement by the respondent. The height of each bar denotes the proportion of CEOs or CFOs who entered that response. Panel B shows the degree to which US and Foreign CEOs, as well as US and Foreign CFOs describe their involvement in decisions about M\&A, capital structure, payout policy, capital allocation and capital investment. A response of '1' means that the respondent makes the decision solely by herself, while a response of ' 7 ' means that the decision is delegated to others with no involvement by the respondent. The height of each bar denotes the proportion of CEOs or CFOs who entered that response. 
TABLE I

Company and CEO Characteristics. This table reports summary statistics for survey responses from U.S. CEOs. Firm sales (size) is determined based on a survey question categorizing firm sales into seven size groups. Category midpoints are used to create the firm size variable reported here with the largest firms represented as $\$ 12.5 \mathrm{~B}$ in the mean and median below. Category 1 includes firms with sales less than $\$ 25 \mathrm{M}$, category 2 between $\$ 25 \mathrm{M}$ and $\$ 99 \mathrm{M}$, category 3 bet ween $\$ 100 \mathrm{M}$ and $\$ 499 \mathrm{M}$, category 4 between $\$ 500 \mathrm{M}$ and $\$ 999 \mathrm{M}$, category 5 between $\$ 1 \mathrm{~B}$ and $\$ 4.9 \mathrm{~B}$, category 6 between $\$ 5 \mathrm{~B}$ and $\$ 9.9 \mathrm{~B}$, and category 7 greater than $\$ 10 \mathrm{~B}$. Public is an indicator for publicly listed firms. Past growth reflects average annual percentage change in sales revenue over the last 3 years. Expected growth reflects projected annual sales revenue growth over the next 3 years. Number of operating segments refers to the number of distinct operating divisions in the firm. Number of acquisitions reflects the number of material acquisitions the firm has made over the past two years. Executive compensation variables (options, bonuses, and salary) are target percentages of total compensation. Variable compensation consists of stock, options, and bonuses. Finance Career is an indicator for executives who, prior to their current job, had work experience focused in financial and/or accounting fields. Tenure is the number of years the executive has been in his/her current position. MBA indicates whether the CEO has a masters of business administration degree. The number of responses varies by variable because not every CEO provided information for every question.

Public (\%)

Sales (Size) Revenue $(\$ M)$

\# Operating Segments

Past Growth (\%)

Expected Growth (\%)

Debt to Assets Ratio (\%)

\# of Acquisitions

Variable Compensation (\% of total)

Salary (\% of total compensation)

Finance Career

Age

Tenure

MBA (\%)

\begin{tabular}{cccccc} 
& & & & \\
$\mathrm{N}$ & Mean & Std. Dev. & Min & Med & Max \\
\hline 785 & $11.5 \%$ & N/A & N/A & N/A & N/A \\
961 & 551.0 & $1,819.3$ & 12.5 & 62.0 & $12,500.0$ \\
1,001 & 2.2 & 1.4 & 1.0 & 2.0 & 12.0 \\
948 & $22.2 \%$ & $45.4 \%$ & $-30.0 \%$ & $12.0 \%$ & $500.0 \%$ \\
952 & $18.6 \%$ & $19.2 \%$ & $-5.0 \%$ & $12.0 \%$ & $99.0 \%$ \\
811 & $28.2 \%$ & $27.6 \%$ & $0.0 \%$ & $20.0 \%$ & $200.0 \%$ \\
& & & & & \\
872 & 0.8 & 1.9 & 0.0 & 0.0 & 26.0 \\
795 & $42.9 \%$ & $26.4 \%$ & $0.0 \%$ & $40.0 \%$ & $100.0 \%$ \\
795 & $57.1 \%$ & $26.4 \%$ & $0.0 \%$ & $60.0 \%$ & $100.0 \%$ \\
986 & $16.0 \%$ & $36.7 \%$ & $0.0 \%$ & $0.0 \%$ & $100.0 \%$ \\
992 & 54.1 & 9.4 & 25.0 & 54.0 & 89.0 \\
1,011 & 10.4 & 8.4 & 0.5 & 8.0 & 56.0 \\
916 & $34.9 \%$ & $47.7 \%$ & $0.0 \%$ & $0.0 \%$ & $100.0 \%$ \\
& & & & \\
\hline
\end{tabular}


Table II

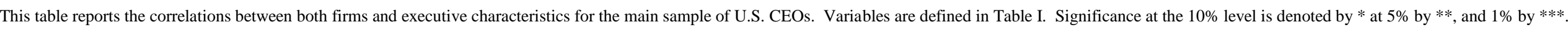

\begin{tabular}{|c|c|c|c|c|c|c|c|c|c|c|}
\hline Public & Firm Size & $\begin{array}{l}\text { \# of Operating } \\
\text { Segments }\end{array}$ & Past Growth & $\begin{array}{l}\text { Expected } \\
\text { Growth }\end{array}$ & $\begin{array}{l}\text { Debt to Asset } \\
\text { Ratio }\end{array}$ & $\begin{array}{l}\text { \# of } \\
\text { Acquisitions }\end{array}$ & $\begin{array}{l}\text { Variable } \\
\text { Comp. }\end{array}$ & Salary & Finance Career Age & Tenure \\
\hline
\end{tabular}

\begin{tabular}{|c|c|c|c|c|c|c|c|c|c|c|c|c|}
\hline Firm Size & $0.371 * *$ & & & & & & & & & & & \\
\hline \# of Operating Segments & $0.076 * *$ & $0.232 * * *$ & & & & & & & & & & \\
\hline Past Growth & -0.035 & -0.035 & -0.030 & & & & & & & & & \\
\hline Expected Growth & -0.052 & $-0.059 *$ & $-0.098 * * *$ & $0.481 * * *$ & & & & & & & & \\
\hline Debt to Asset Ratio & 0.012 & 0.028 & 0.018 & -0.046 & -0.044 & & & & & & & \\
\hline Variable Comp. & $0.172 * * *$ & $0.174 * * *$ & $0.072 * * *$ & 0.021 & 0.096 & -0.022 & 0.067 & & & & & \\
\hline Salary & $-0.172 * * *$ & $-0.174 * * *$ & $-0.072 * *$ & -0.021 & $-0.096 * * *$ & 0.022 & -0.067 & $-1.000 * * *$ & & & & \\
\hline Finance Career & -0.012 & 0.043 & -0.024 & -0.042 & 0.009 & $0.133 * * *$ & -0.069 & $0.110 *$ & $-0.110 * * *$ & & & \\
\hline Age & 0.015 & -0.001 & 0.047 & $-0.177 * * *$ & $-0.305 * * *$ & 0.010 & -0.036 & $-0.107 * *$ & $0.107 * * *$ & $-0.062 *$ & & \\
\hline Tenure & $-0.156 * * *$ & $-0.095 * *$ & 0.019 & $-0.113 * * *$ & $-0.174 * * *$ & 0.008 & $-0.028 * *$ & $-0.054 * * *$ & 0.054 & $-0.057 *$ & $0.465 * * *$ & \\
\hline MBA & 0.005 & -0.009 & $-0.064 *$ & $0.066 *$ & $0.087 * *$ & 0.020 & -0.034 & 0.025 & -0.025 & $0.172 * * *$ & $-0.150 * * *$ & $-0.106 * * *$ \\
\hline
\end{tabular}


This table examines the rules that executives follow when allocating capital within the firm. An executive considers a rule to be important ("\% impt") in his/her allocation of capital across divisions if he/she answers 4 or 5 on a Scale of 5 with 1 = "Not at All Important" and $5=$ "Very Important" on the following factors: NPV Rank - "NPV Ranking of Project", Manager Reputation - "The Reputation of the Divisional Manager in Terms of Delivering on Previous Projects", Manager Confidence - "The Confidence of the Divisional Manager in the Project", Cash Flow Timing - "Timing of Projects' Cash Flows", Market Share - "Protecting Market Share", Previous Return - "Return on Previous Projects Earned by the Division Proposing the Project", "Gut Feel" - Senior Management's Gut Feel", Internal/External - "Whether the Project Requires External Capital (vs. Funding with Internal Funds)", Corporate Politics -

"Corporate Politics", Balanced Allocation - "Moving Towards an Even Balance of Capital Allocation Across Divisions".

Panel A performs the analysis for all executives, while Panel B considers only executives who indicate that the Internal/External split is important (i.e., answered 4 or 5 for this factor). The following means are tested for statistical differences: US CEO vs US CFO, NON US CEO vs US CEO, and NON US CFO vs US CFO, with significance at the $10 \%$ level is denoted by *, $5 \%$ by **, and $1 \%$ by ***.

Panel A

Capital Allocation

(All Repondents)

\begin{tabular}{|c|c|c|c|c|c|c|c|c|}
\hline & & US CEO & & US CFO & & N US CEO & & N US CFO \\
\hline & Mean & \%impt & Mean & \%impt & Mean & \%impt & Mean & \%impt \\
\hline NPV Rank & 3.94 & $78.6 \%$ & 3.73 & $70.1 \% * * *$ & 3.83 & $75.6 \%$ & 3.77 & $70.4 \%$ \\
\hline Manager Reputation & 3.80 & $71.3 \%$ & 3.64 & $66.0 \% *$ & 3.62 & $61.3 \% * *$ & 3.60 & $64.0 \%$ \\
\hline Cash Flow Timing & 3.72 & $65.3 \%$ & 3.70 & $64.9 \%$ & 3.97 & $73.4 \%$ & 3.92 & $74.7 \% * * *$ \\
\hline Market Share & 3.38 & $52.9 \%$ & 3.43 & $56.0 \%$ & 3.48 & $55.7 \%$ & 3.64 & $60.0 \%$ \\
\hline Internal / External & 3.24 & $43.9 \%$ & 3.03 & $40.4 \%$ & 3.35 & $50.0 \%$ & 3.19 & $41.3 \%$ \\
\hline Corporate Politics & 1.94 & $9.5 \%$ & 2.69 & $23.3 \% * * *$ & 2.46 & $17.7 \% * * *$ & 3.05 & $35.8 \% * * *$ \\
\hline Balanced Allocation & 1.74 & $6.9 \%$ & 1.82 & $5.8 \%$ & 2.16 & $13.6 \% * *$ & 2.37 & $17.9 \% * * *$ \\
\hline
\end{tabular}

Panel B

\section{Capital Allocation}

(Respondents who expressed that the need for external funds is an important decision criterion)

\begin{tabular}{|c|c|c|c|c|c|c|c|c|}
\hline & \multirow{2}{*}{\multicolumn{2}{|c|}{ US CEO }} & \multirow{2}{*}{\multicolumn{2}{|c|}{$\begin{array}{c}\text { US CFO } \\
\% \text { impt }\end{array}$}} & \multicolumn{2}{|c|}{ NON US CEO } & \multicolumn{2}{|c|}{ NON US CFO } \\
\hline & Mean & & & & Mean & \%impt & Mean & \%impt \\
\hline NPV Rank & 4.09 & $83.2 \%$ & 3.88 & $74.6 \% * *$ & 4.18 & $93.5 \% *$ & 3.89 & $74.9 \%$ \\
\hline Manager Reputation & 3.93 & $76.1 \%$ & 3.89 & $76.2 \%$ & 3.94 & $75.8 \%$ & 3.71 & $70.4 \%$ \\
\hline Manager Confidence & 3.87 & $69.9 \%$ & 3.68 & $65.0 \%$ & 3.87 & $64.5 \%$ & 3.77 & $68.1 \%$ \\
\hline Cash Flow Timing & 3.99 & $79.5 \%$ & 3.97 & $77.3 \%$ & 4.24 & $88.7 \%$ & 4.14 & $84.5 \% *$ \\
\hline Market Share & 3.44 & $55.0 \%$ & 3.44 & $58.0 \%$ & 3.65 & $62.9 \%$ & 3.72 & $63.8 \%$ \\
\hline Previous Return & 3.46 & $48.8 \%$ & 3.69 & $63.9 \% * * *$ & 4.00 & $71.0 \% * * *$ & 4.05 & $78.8 \% * * *$ \\
\hline Gut Feel & 3.51 & $54.3 \%$ & 3.24 & $40.9 \% * * *$ & 3.29 & $45.2 \%$ & 3.15 & $38.7 \%$ \\
\hline Corporate Politics & 1.95 & $9.9 \%$ & 2.79 & $23.2 \% * * *$ & 2.44 & $21.0 \% * * *$ & 3.13 & $39.2 \% * * *$ \\
\hline Balanced Allocation & 1.93 & $10.7 \%$ & 1.93 & $7.7 \%$ & 2.42 & $19.4 \% * *$ & 2.61 & $24.5 \% * * *$ \\
\hline
\end{tabular}




\section{Table IV}

This table reports the correlations between factors that are hypothesized to affect capital allocation policies for the main sample of U.S. CEOs. Variables are defined in Table III. Significance at the $10 \%$ level is denoted by ${ }^{*}, 5 \%$ by ${ }^{* *}$, and $1 \%$ by ${ }^{* * *}$. P values are provided in parenthesis.

\begin{tabular}{|c|c|c|c|c|c|c|c|c|c|}
\hline & NPV Rank & $\begin{array}{l}\text { Manager } \\
\text { Reputation }\end{array}$ & $\begin{array}{l}\text { Manager } \\
\text { Confidence }\end{array}$ & $\begin{array}{l}\text { Cash } \\
\text { Flow Timing }\end{array}$ & Market Share & $\begin{array}{l}\text { Previous } \\
\text { Return }\end{array}$ & Gut Feel & $\begin{array}{c}\text { Internal / } \\
\text { External }\end{array}$ & $\begin{array}{l}\text { Corporate } \\
\text { Politics }\end{array}$ \\
\hline Manager Reputation & $\begin{array}{l}0.346^{* * *} \\
(0.000)\end{array}$ & & & & & & & & \\
\hline Manager Confidence & $\begin{array}{l}0.264^{* * *} \\
(0.000)\end{array}$ & $\begin{array}{l}0.302^{* * *} \\
(0.000)\end{array}$ & & & & & & & \\
\hline Cash Flow Timing & $\begin{array}{l}0.130 * * * \\
(0.000)\end{array}$ & $\begin{array}{l}0.088^{* * *} \\
(0.013)\end{array}$ & $\begin{array}{l}0.100 * * * \\
(0.005)\end{array}$ & & & & & & \\
\hline Market Share & $\begin{array}{l}0.117 * * * \\
(0.001)\end{array}$ & $\begin{array}{l}0.117 * * * \\
(0.001)\end{array}$ & $\begin{array}{l}0.157 * * * \\
(0.000)\end{array}$ & $\begin{array}{l}0.141^{* * *} \\
(0.000)\end{array}$ & & & & & \\
\hline Previous Return & $\begin{array}{l}0.165^{* * *} \\
(0.000)\end{array}$ & $\begin{array}{l}0.117 * * * \\
(0.001)\end{array}$ & $\begin{array}{l}0.176^{* * *} \\
(0.000)\end{array}$ & $\begin{array}{l}0.082 * * \\
(0.022)\end{array}$ & $\begin{array}{l}-0.022 \\
(0.541)\end{array}$ & & & & \\
\hline Gut Feel & $\begin{array}{l}0.085^{* *} \\
(0.017)\end{array}$ & $\begin{array}{l}0.137 * * * \\
(0.000)\end{array}$ & $\begin{array}{l}0.167 * * * \\
(0.000)\end{array}$ & $\begin{array}{l}0.031 \\
(0.389)\end{array}$ & $\begin{array}{l}0.030 \\
(0.401)\end{array}$ & $\begin{array}{l}-0.035 \\
(0.331)\end{array}$ & & & \\
\hline Internal / External & $\begin{array}{l}0.100 * * * \\
(0.005)\end{array}$ & $\begin{array}{l}0.088 * * \\
(0.013)\end{array}$ & $\begin{array}{l}0.021 \\
(0.549)\end{array}$ & $\begin{array}{l}0.266^{* * *} \\
(0.000)\end{array}$ & $\begin{array}{l}0.040 \\
(0.263)\end{array}$ & $\begin{array}{l}-0.043 \\
(0.228)\end{array}$ & $\begin{array}{l}0.114^{* * *} \\
(0.001)\end{array}$ & & \\
\hline Corporate Politics & $\begin{array}{l}-0.065^{*} \\
(0.068)\end{array}$ & $\begin{array}{l}-0.028 \\
(0.434)\end{array}$ & $\begin{array}{l}0.040 \\
(0.266)\end{array}$ & $\begin{array}{l}0.054 \\
(0.131)\end{array}$ & $\begin{array}{l}0.077^{* *} \\
(0.031)\end{array}$ & $\begin{array}{l}-0.087 * * \\
(0.015)\end{array}$ & $\begin{array}{l}0.077^{* *} \\
(0.031)\end{array}$ & $\begin{array}{l}0.010 \\
(0.782)\end{array}$ & \\
\hline Balanced Allocation & $\begin{array}{l}-0.040 \\
(0.266)\end{array}$ & $\begin{array}{l}0.041 \\
(0.249)\end{array}$ & $\begin{array}{l}0.032 \\
(0.363)\end{array}$ & $\begin{array}{l}0.029 \\
(0.409)\end{array}$ & $\begin{array}{l}0.029 \\
(0.412)\end{array}$ & $\begin{array}{l}-0.006 \\
(0.864)\end{array}$ & $\begin{array}{l}0.034 \\
(0.332)\end{array}$ & $\begin{array}{l}0.129 * * * \\
(0.000)\end{array}$ & $\begin{array}{l}0.135^{* * *} \\
(0.000)\end{array}$ \\
\hline
\end{tabular}


This table describes who within a company makes corporate decisions and how much these decisions are delegated. Survey participants are asked to rank on a scale of $1=$ high to $7=$ low their involvement in five different financial decisions. Panel A reports the percentage of participants who answered "1" indicating that an executive dominates a given corporate decision without any help from others. In other words, there is no delegation of decision making authority. Panel B reports the percentage of participants who answered "1" or "2". Panel C reports the percentage of participants who answered "7", indicating that an executive has a minimal role in the given corporate decision. In other words, the decision is completely delegated to or made by others. Panel D reports the percentage of participants who answered "6" or "7". Significance is between US CEOs and US CFOs. Significance between CEO and CFO responses at the $10 \%$ level is denoted by *, $5 \%$ by **, and $1 \%$ by ***. This analysis is based on responses from 950 U.S. based CEOs and 525 U.S. based CFOs.

Panel A: Respondents who answered "1"

\begin{tabular}{lccccc} 
& \multicolumn{2}{c}{ US CEOs } & \multicolumn{2}{c}{ US CFOs } & \\
& Rank & $\%$ & Rank & $\%$ & \\
\cline { 2 - 6 } $\begin{array}{l}\text { Mergers \& } \\
\text { Acquisitions }\end{array}$ & 2.9 & 15.4 & 4.6 & 0.6 & $* * *$ \\
Capital Structure & 3.0 & 15.1 & 4.1 & 3.1 & $* * *$ \\
Payout & 3.0 & 13.7 & 4.5 & 1.9 & $* * *$ \\
Capital Allocation & 3.0 & 13.4 & 4.2 & 2.7 & $* * *$ \\
Investment & 3.0 & 10.6 & 4.1 & 1.3 & $* * *$ \\
\cline { 2 - 6 } & & & & &
\end{tabular}

Panel B: Respondents who answered "1" or "2"

\begin{tabular}{lccccc} 
& \multicolumn{2}{c}{ US CEOs } & \multicolumn{2}{c}{ US CFOs } & \\
& Rank & $\%$ & Rank & $\%$ & \\
\cline { 2 - 6 } $\begin{array}{l}\text { Mergers \& } \\
\text { Acquisitions }\end{array}$ & 2.9 & 46.5 & 4.6 & 9.5 & $* * *$ \\
Capital Structure & 3.0 & 39.5 & 4.1 & 23.9 & $* * *$ \\
Payout & 3.0 & 38.7 & 4.5 & 14.3 & $* * *$ \\
Capital Allocation & 3.0 & 38.1 & 4.2 & 19.2 & $* * *$ \\
Investment & 3.0 & 36.3 & 4.1 & 13.8 & $* * *$ \\
\hline
\end{tabular}

Panel C: Respondents who answered "7"

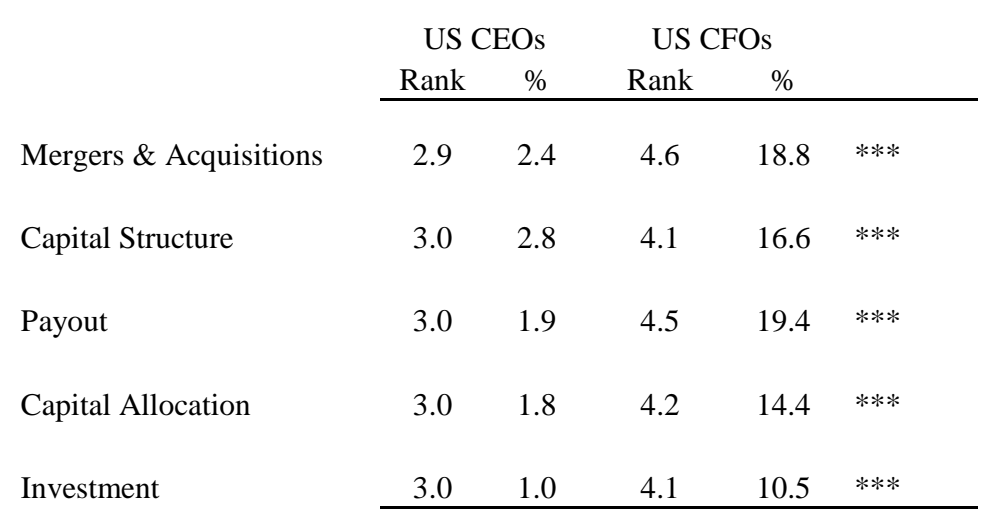

Panel D: Respondents who answered "6" or "7"

\begin{tabular}{lccccc} 
& \multicolumn{2}{c}{ US CEOs } & \multicolumn{2}{c}{ US CFOs } & \\
& Rank & $\%$ & Rank & $\%$ & \\
\cline { 2 - 6 } Mergers \& Acquisitions & 2.9 & 4.7 & 4.6 & 30.9 & $* * *$ \\
Capital Structure & 3.0 & 4.7 & 4.1 & 25.6 & $* * *$ \\
Payout & 3.0 & 3.6 & 4.5 & 29.3 & $* * *$ \\
Capital Allocation & 3.0 & 4.2 & 4.2 & 23.2 & $* * *$ \\
Investment & 3.0 & 2.5 & 4.1 & 18.4 & $* * *$ \\
\cline { 2 - 6 } & & & & &
\end{tabular}


This table presents results from ordered logit regressions of U.S. CEO's delegation of decision-authority on firm and executive characteristics. The dependent variable measures degree of delegation in capital structure decisions. Responses are on a scale of 1 to 7 with 1 = "I Make the Decision Without the Help From Others" and 7 = "Others Make Decision". For the dependent variable, this degree of delegation is split into 3 buckets: 0 (if the respondent answered 1 or 2), 1 (if the respondent answered 3 or 4), and 2 (if the respondent answered 5, 6 or 7). Variable Compensation, Finance Career, MBA and Public are as defined in Table 1. All other variables in this regression have been recoded as binary indicator variables. Segments takes the value of 1 if the firm has more than two distinct operating units, while Size is 1 if the firm has annual sales revenue greater than $\$ 1$ billion. Tenure is 1 if time spent by the executive in current position is greater than the median of 8 years. Expected Growth is coded to 1 if reported projected annual sales revenue growth is in the upper 75th percentile of responses. Manufacturing and Tech are 1 if respondents' firms are in the manufacturing or technology (software / biotechnology) industries respectively. Old is 1 if the respondents' age is greater than the median US CEO's age (54 years), and Acquisitions is 1 if the firm has acquired at least 1 company in the last 2 years. Multiple Acquisitions is 1 if the company has acquired 2 or more companies in the last 2 years. A positive coefficient indicates that delegation increases as the explanatory variable increases. Column 7 shows the percentage increase or decrease in the odds of being in a higher bucket as the explanatory variable increases. Standard errors are clustered by CEO. Significance at the $10 \%$ level is denoted by $*, 5 \%$ by **, and $1 \%$ by $* * *$. T-statistics are provided in parentheses.

\begin{tabular}{|c|c|c|c|c|c|c|c|c|}
\hline Panel A & $\begin{array}{l}\text { Predicted } \\
\text { Sign }\end{array}$ & (1) & (2) & (3) & (4) & (5) & (6) & (7) \\
\hline Segments & + & $\begin{array}{l}0.676^{* * *} \\
(4.85)\end{array}$ & $\begin{array}{l}0.738^{* * * *} \\
(4.79)\end{array}$ & $\begin{array}{l}0.753^{* * *} \\
(4.88)\end{array}$ & $\begin{array}{l}0.749 * * * \\
(4.80)\end{array}$ & $\begin{array}{l}0.732 * * * \\
(4.57)\end{array}$ & $\begin{array}{l}0.792^{* * *} \\
(4.48)\end{array}$ & $120.78 \%$ \\
\hline Size & + & $\begin{array}{l}0.951^{* * *} \\
(4.00)\end{array}$ & $\begin{array}{l}0.880^{* * * *} \\
(3.11)\end{array}$ & $\begin{array}{l}0.851^{* * *} \\
(2.96)\end{array}$ & $\begin{array}{l}0.832^{* * *} \\
(2.78)\end{array}$ & $\begin{array}{l}0.816^{* * *} \\
(2.68)\end{array}$ & $\begin{array}{l}0.541 \\
(1.60)\end{array}$ & $71.77 \%$ \\
\hline Tenure & - & $\begin{array}{l}- \\
0.556^{* * *} \\
(4.25)\end{array}$ & $\begin{array}{l}- \\
0.521^{* * * *} \\
(3.62)\end{array}$ & $\begin{array}{l}- \\
0.488^{* * *} \\
(3.32)\end{array}$ & $\begin{array}{l}-0.543^{* * * *} \\
(3.41)\end{array}$ & $\begin{array}{l}-0.534^{* * *} \\
(3.33)\end{array}$ & $\begin{array}{l}-0.538 * * * \\
(3.06)\end{array}$ & $-41.61 \%$ \\
\hline Expected Growth & - & $\begin{array}{l}- \\
0.428^{* * *} \\
(2.83)\end{array}$ & $\begin{array}{l}-0.406^{* *} \\
(2.46)\end{array}$ & $\begin{array}{l}-0.430 * * \\
(2.56)\end{array}$ & $\begin{array}{l}-0.459 * * * \\
(2.69)\end{array}$ & $\begin{array}{l}-0.466^{* * *} \\
(2.70)\end{array}$ & $\begin{array}{l}-0.306 \\
(1.56)\end{array}$ & $-26.36 \%$ \\
\hline Variable Compensation & ? & & $\begin{array}{l}-0.002 \\
(0.72)\end{array}$ & $\begin{array}{l}-0.002 \\
(0.62)\end{array}$ & $\begin{array}{l}-0.002 \\
(0.76)\end{array}$ & $\begin{array}{l}-0.002 \\
(0.77)\end{array}$ & $\begin{array}{l}-0.004 \\
(1.31)\end{array}$ & $-0.40 \%$ \\
\hline Manufacturing & - & & & $\begin{array}{l}0.266 \\
(1.41)\end{array}$ & $\begin{array}{l}0.258 \\
(1.32)\end{array}$ & $\begin{array}{l}0.241 \\
(1.22)\end{array}$ & $\begin{array}{l}0.094 \\
(0.42)\end{array}$ & $9.86 \%$ \\
\hline Tech & + & & & $\begin{array}{l}0.316 \\
(1.33)\end{array}$ & $\begin{array}{l}0.320 \\
(1.34)\end{array}$ & $\begin{array}{l}0.316 \\
(1.31)\end{array}$ & $\begin{array}{l}0.181 \\
(0.71)\end{array}$ & $19.84 \%$ \\
\hline Finance Career & - & & & & $\begin{array}{l}-0.334 \\
(1.57)\end{array}$ & $\begin{array}{l}-0.320 \\
(1.51)\end{array}$ & $\begin{array}{l}-0.151 \\
(0.63)\end{array}$ & $-14.02 \%$ \\
\hline Old & - & & & & $\begin{array}{l}0.138 \\
(0.84)\end{array}$ & $\begin{array}{l}0.160 \\
(0.97)\end{array}$ & $\begin{array}{l}0.238 \\
(1.33)\end{array}$ & $26.87 \%$ \\
\hline Acquisitions & + & & & & & $\begin{array}{l}0.117 \\
(0.71)\end{array}$ & $\begin{array}{l}-0.232 \\
(1.02)\end{array}$ & $-20.71 \%$ \\
\hline Multiple Acquisitions & + & & & & & & $\begin{array}{l}0.540 * \\
(1.87)\end{array}$ & $71.60 \%$ \\
\hline MBA & - & & & & & & $\begin{array}{l}-0.174 \\
(0.98)\end{array}$ & $-15.97 \%$ \\
\hline Public & & & & & & & $\begin{array}{l}0.478^{*} \\
(1.81)\end{array}$ & $61.28 \%$ \\
\hline Observations & & 4613 & 3847 & 3832 & 3752 & 3720 & 3185 & \\
\hline Log Likelihood & & -4065.4 & -3384.5 & -3366.0 & -3289.3 & -3255.1 & -2782.4 & \\
\hline Pseudo R2 & & $2.64 \%$ & $2.57 \%$ & $2.74 \%$ & $3.16 \%$ & $3.24 \%$ & $3.97 \%$ & \\
\hline
\end{tabular}


Table VIB - Delegation of Corporate Policies

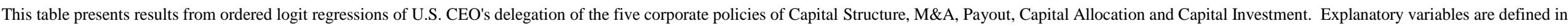

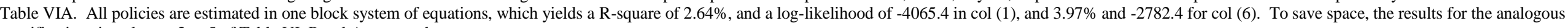
specifications in columns 2 to 5 of Table VI, Panel A are not shown

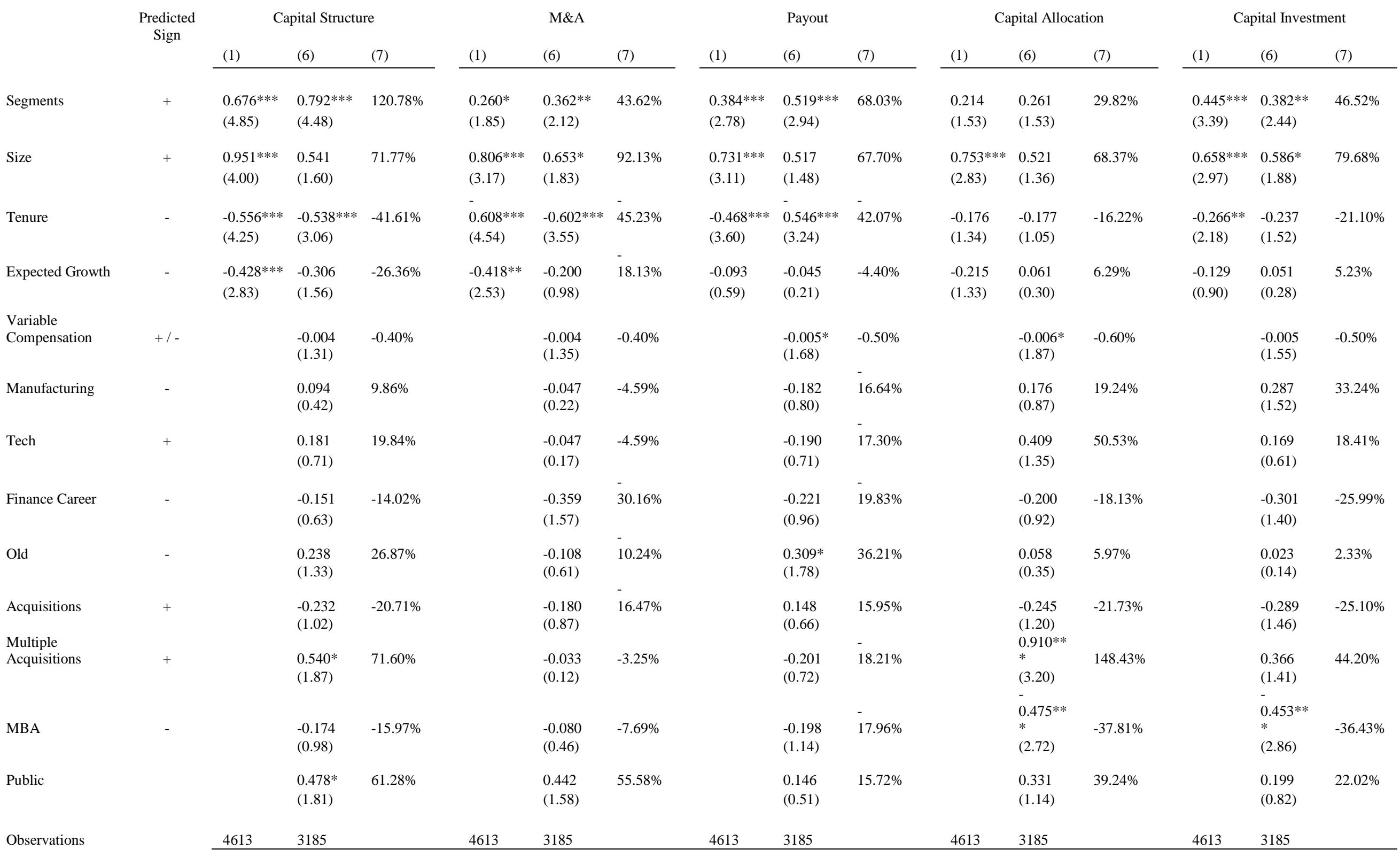


Delegation Regressions Constraining Estimated Coefficients to be Equal Across all Five Policies. This table presents results from ordered logit regressions of U.S. CEO's delegation of decision-authority on firm and executive characteristics. The specification includes a stacked system of five corporate policies, with dependent variables measuring degree of delegation in capital structure, M\&A, payout, capital allocation, and capital investment decisions. In this table, the coefficient for any given variable is constrained to be equal across all five equations. Responses are on a scale of 1 to 7 with 1 = "I Make the Decision Without the Help From Others" and 7 = "Others Make Decision". For the dependent variable, this degree of delegation is split into 3 buckets: 0 (if the respondent answered 1 or 2), 1 (if the respondent answered 3 or 4 ), and 2 (if the respondent answered 5, 6, or 7). Explanatory variables are defined in Table VIA. A positive coefficient indicates that delegation increases as the explanatory variable increases. Column 7 shows the percentage increase or decrease in the odds of being in a higher bucket as the explanatory variable increases. Standard errors are clustered by CEO. Significance at the $10 \%$ level is denoted by $*, 5 \%$ by $* *$, and $1 \%$ by $* * *$. T-statistics are provided in parentheses. A significant p-value for the likelihood ratio test in the second to last row indicates a difference in the estimated coefficients from Table VI (which are free for each corporate policy regression) vs. those in Table VII (which are constrained to be equal across all five regressions).

\begin{tabular}{|c|c|c|c|c|c|c|c|c|}
\hline & $\begin{array}{l}\text { Predicted } \\
\text { Sign }\end{array}$ & $(1)$ & $(2)$ & (3) & $(4)$ & $(5)$ & (6) & $(7)$ \\
\hline Segments & + & $\begin{array}{l}0.394^{* * * *} \\
(3.85)\end{array}$ & $\begin{array}{l}0.423 * * * \\
(3.79)\end{array}$ & $\begin{array}{l}0.430 * * * \\
(3.84)\end{array}$ & $\begin{array}{l}0.440 * * * \\
(3.90)\end{array}$ & $\begin{array}{l}0.444^{* * * *} \\
(3.89)\end{array}$ & $\begin{array}{l}0.453^{* * *} \\
(3.65)\end{array}$ & $57.30 \%$ \\
\hline Size & + & $\begin{array}{l}0.775^{* * *} \\
(3.47)\end{array}$ & $\begin{array}{l}0.756^{* * *} \\
(2.89)\end{array}$ & $\begin{array}{l}0.750^{* * *} \\
(2.86)\end{array}$ & $\begin{array}{l}0.759 * * * \\
(2.82)\end{array}$ & $\begin{array}{l}0.762 * * * \\
(2.79)\end{array}$ & $\begin{array}{l}0.551 * \\
(1.77)\end{array}$ & $73.50 \%$ \\
\hline Tenure & - & $\begin{array}{l}-0.411^{* * *} \\
(4.16)\end{array}$ & $\begin{array}{l}-0.393^{* * *} \\
(3.63)\end{array}$ & $\begin{array}{l}-0.363^{* * * *} \\
(3.32)\end{array}$ & $\begin{array}{l}-0.411^{* * *} \\
(3.58)\end{array}$ & $\begin{array}{l}-0.403^{* * *} \\
(3.49)\end{array}$ & $\begin{array}{l}-0.416^{* * *} \\
(3.34)\end{array}$ & $-34.03 \%$ \\
\hline Expected Growth & - & $\begin{array}{l}-0.256^{* *} \\
(2.14)\end{array}$ & $\begin{array}{l}-0.190 \\
(1.44)\end{array}$ & $\begin{array}{l}-0.201 \\
(1.50)\end{array}$ & $\begin{array}{l}-0.212 \\
(1.56)\end{array}$ & $\begin{array}{l}-0.215 \\
(1.56)\end{array}$ & $\begin{array}{l}-0.088 \\
(0.59)\end{array}$ & $-8.42 \%$ \\
\hline Variable Compensation & $+1-$ & & $\begin{array}{l}-0.003 \\
(1.54)\end{array}$ & $\begin{array}{l}-0.003 \\
(1.45)\end{array}$ & $\begin{array}{l}-0.004^{*} \\
(1.77)\end{array}$ & $\begin{array}{l}-0.004^{*} \\
(1.74)\end{array}$ & $\begin{array}{l}-0.005^{* *} \\
(2.04)\end{array}$ & $-0.50 \%$ \\
\hline Manufacturing & - & & & $\begin{array}{l}0.191 \\
(1.44)\end{array}$ & $\begin{array}{l}0.188 \\
(1.39)\end{array}$ & $\begin{array}{l}0.199 \\
(1.47)\end{array}$ & $\begin{array}{l}0.072 \\
(0.49)\end{array}$ & $7.47 \%$ \\
\hline Tech & + & & & $\begin{array}{l}0.207 \\
(1.15)\end{array}$ & $\begin{array}{l}0.203 \\
(1.10)\end{array}$ & $\begin{array}{l}0.216 \\
(1.18)\end{array}$ & $\begin{array}{l}0.105 \\
(0.53)\end{array}$ & $11.07 \%$ \\
\hline Finance Career & - & & & & $\begin{array}{l}-0.295^{* *} \\
(1.97)\end{array}$ & $\begin{array}{l}-0.286 * \\
(1.91)\end{array}$ & $\begin{array}{l}-0.247 \\
(1.50)\end{array}$ & $-21.89 \%$ \\
\hline Old & - & & & & $\begin{array}{l}0.054 \\
(0.47)\end{array}$ & $\begin{array}{l}0.072 \\
(0.62)\end{array}$ & $\begin{array}{l}0.102 \\
(0.84)\end{array}$ & $10.74 \%$ \\
\hline Acquisitions & + & & & & & $\begin{array}{l}0.005 \\
(0.04)\end{array}$ & $\begin{array}{l}-0.160 \\
(1.04)\end{array}$ & $-14.79 \%$ \\
\hline Multiple Acquisitions & + & & & & & & $\begin{array}{l}0.309 \\
(1.54)\end{array}$ & $36.21 \%$ \\
\hline MBA & - & & & & & & $\begin{array}{l}-0.276^{* *} \\
(2.19)\end{array}$ & $-24.12 \%$ \\
\hline Public & & & & & & & $\begin{array}{l}0.324 * \\
(1.69)\end{array}$ & $38.26 \%$ \\
\hline Observations & & 4613 & 3847 & 3832 & 3752 & 3720 & 3185 & \\
\hline Log Likelihood & & -4085.9 & -3402.0 & -3386.4 & -3311.8 & -3279.5 & -2812.3 & \\
\hline $\begin{array}{l}\text { p-value: LRT comparing } \\
\text { VII vs.VI coeffs }\end{array}$ & & 0.0005 & 0.0534 & 0.0549 & 0.1445 & 0.1585 & 0.2131 & \\
\hline Pseudo R2 & & $2.15 \%$ & $2.07 \%$ & $2.15 \%$ & $2.50 \%$ & $2.51 \%$ & $2.94 \%$ & \\
\hline
\end{tabular}




\section{Appendix}

Table A

This table compares the survey sample of the firms under the management of US CEOs to the Compustat universe using survey variable definitions. The survey data are matched against the 2005 annual Compustat data because our survey was conducted in early 2006, which should reflect 2005 financials. Sales is represented by seven size categories. Category 1 includes firms with sales less than $\$ 25 \mathrm{M}$, category 2 between $\$ 25 \mathrm{M}$ and $\$ 99 \mathrm{M}$, category 3 between $\$ 100 \mathrm{M}$ and $\$ 499 \mathrm{M}$, category 4 between $\$ 500 \mathrm{M}$ and $\$ 999 \mathrm{M}$, category 5 between $\$ 1 \mathrm{~B}$ and $\$ 4.9 \mathrm{~B}$, category 6 between $\$ 5 \mathrm{~B}$ and $\$ 9.9 \mathrm{~B}$, and category 7 includes firms with $\$ 10 \mathrm{~B}$ or above in sales. Debt to assets ratio, payout ratio (dividends as a fraction of earnings), and historical growth (average annual percentage change in sales revenue over the last 3 years) are reported by the US CEO survey respondent. Sample \% shows the percentage of survey firms falling in a given Compustat quintile. Due to the frequency of similar responses to payout ratio, breaking the survey sample and Compustat sample into 5 quintiles was not possible. From our sample, responses for payout ratio corresponded to only 2 of the Compustat buckets.

\begin{tabular}{|c|c|c|c|c|c|c|c|c|}
\hline $\begin{array}{l}\text { Panel A } \\
\text { Comparison to Cor }\end{array}$ & Universe Using & irvey Var & Definitior & ll Surv & Firms) & & & \\
\hline & & Sample & Sample & & mpust & breakpc & nt quir & \\
\hline Variable & & average & median & 1 & 2 & 3 & 4 & 5 \\
\hline & Universe avg. & & & 1.0 & 1.7 & 2.8 & 3.9 & 5.7 \\
\hline Sales & Sample avg. & 2.2 & 2.0 & 1.0 & 2.0 & 3.0 & 4.5 & 6.6 \\
\hline & Sample \% & & & 40.4 & 27.1 & 20.5 & 9.1 & 2.9 \\
\hline & Universe avg. & & & 0.0 & 0.0 & 0.2 & 0.3 & 1.0 \\
\hline Debt/Assets* & Sample avg. & 0.3 & 0.2 & 0.0 & 0.1 & 0.2 & 0.3 & 0.7 \\
\hline & Sample \% & & & 19.5 & 17.0 & 16.3 & 22.7 & 24.4 \\
\hline & Universe avg. & & & & & $0.0 \%$ & & $46.2 \%$ \\
\hline Payout Ratio & Sample avg. & $20.7 \%$ & $0.0 \%$ & & & $0.0 \%$ & & $41.6 \%$ \\
\hline & Sample \% & & & & & $50.3 \%$ & & $49.7 \%$ \\
\hline & Universe avg. & & & -0.2 & 0.0 & 0.1 & 0.2 & 1.7 \\
\hline Historical Growth & Sample avg. & 0.2 & 0.1 & -0.2 & 0.0 & 0.1 & 0.2 & 1.0 \\
\hline & Sample \% & & & 1.0 & 28.0 & 35.8 & 22.5 & 12.8 \\
\hline Panel B & & & & & & & & \\
\hline Comparison to $\mathrm{Col}$ & Universe Using & trvey Var & Definitior & $O P u b$ & Survey & irms) & & \\
\hline & & Sample & Sample & & mpust & breakpc & nt quir & \\
\hline Variable & & average & median & 1 & 2 & 3 & 4 & 5 \\
\hline & Universe avg. & & & 1.0 & 1.7 & 2.8 & 3.9 & 5.7 \\
\hline Sales & Sample avg. & 3.7 & 3.0 & 1.0 & 2.0 & 3.0 & 4.6 & 6.7 \\
\hline & Sample \% & & & 10.1 & 16.9 & 27.0 & 31.5 & 14.6 \\
\hline & Universe avg. & & & 0.0 & 0.0 & 0.2 & 0.3 & 1.0 \\
\hline Debt/Assets & Sample avg. & 0.3 & 0.3 & 0.0 & 0.1 & 0.2 & 0.3 & 0.7 \\
\hline & Sample \% & & & 16.7 & 16.7 & 12.8 & 30.8 & 23.1 \\
\hline & Universe avg. & & & & & $0.0 \%$ & & $46.2 \%$ \\
\hline Payout Ratio & Sample avg. & $20.8 \%$ & $0.0 \%$ & & & $0.0 \%$ & & $34.1 \%$ \\
\hline & Sample \% & & & & & $48.6 \%$ & & $51.4 \%$ \\
\hline & Universe avg. & & & -0.2 & 0.0 & 0.1 & 0.2 & 1.7 \\
\hline Historical Growth & Sample avg. & 0.2 & 0.1 & -0.1 & 0.0 & 0.1 & 0.2 & 0.7 \\
\hline & Sample \% & & & 2.2 & 37.1 & 23.6 & 24.7 & 12.4 \\
\hline
\end{tabular}

